\title{
Review Article \\ Inflammatory Mediators of Leprosy Reactional Episodes and Dental Infections: A Systematic Review
}

\author{
D. C. B. Cortela, ${ }^{1}$ A. L. de Souza Junior, ${ }^{1}$ M. C. L. Virmond, ${ }^{2}$ and E. Ignotti ${ }^{1}$ \\ ${ }^{1}$ School of Health Sciences, State University of Mato Grosso, São João Street, S/N, 78000-000 Cáceres, MT, Brazil \\ ${ }^{2}$ Research Department, Instituto Lauro de Souza Lima, Comandante J. R. Barros Rodovia Km 225/226, 17034-971 Bauru, SP, Brazil \\ Correspondence should be addressed to D. C. B. Cortela; denisecortela@hotmail.com
}

Received 11 March 2015; Accepted 19 May 2015

Academic Editor: Javier Fernandez-Solari

Copyright (c) 2015 D. C. B. Cortela et al. This is an open access article distributed under the Creative Commons Attribution License, which permits unrestricted use, distribution, and reproduction in any medium, provided the original work is properly cited.

\begin{abstract}
Reactional episodes in leprosy are a result of complex interactions between the immune system, Mycobacterium leprae, and predisposing factors, including dental infections. To determine the main inflammatory mediators in the immunopathological process of dental infections and leprosy reactions, we conducted a systematic review of primary literature published between 1996 and 2013. A three-stage literature search was performed (Stage I, "leprosy reactions" and "inflammatory mediators"; Stage II, "dental infections" and "inflammatory mediators"; and Stage III, "leprosy reactions," "dental infections," and "inflammatory mediators"). Of the 911 eligible publications, 10 were selected in Stage I, 68 in Stage II, and 1 in Stage III. Of the 27 studied inflammatory mediators, the main proinflammatory mediators were IL-6, IFN- $\gamma$, TNF- $\alpha$, IL-1 $\beta$, and IL-17; the main anti-inflammatory mediators were IL10 and IL-4. Serum IL-6 and TNF- $\alpha$ concentrations were significant during periodontal and reactional lesion evolution; IFN- $\gamma$ and IL-1 $\beta$ were associated with types 1 and 2 reactions and chronic periodontal disease. The proinflammatory mediators in dental infections and leprosy reactions, especially IL- 6 and TNF- $\alpha$, were similar across studies, regardless of the laboratory technique and sample type. IFN- $\gamma$ and IL-1 $\beta$ were significant for leprosy reactions and periodontal diseases. This pattern was maintained in serum.
\end{abstract}

\section{Introduction}

Leprosy reactions are sudden acute immune-inflammation episodes against Mycobacterium leprae superimposed on the chronic course of leprosy. They predominate in individuals classified as multibacillary and are responsible for irreversible nerve damage, increasing the disease burden and associated stigma [1].

Identified as type 1 reactions (T1Rs), type 2 reactions (T2Rs), or neurological reactions, leprosy reactions show distinct immunological characteristics and may occur before or during treatment as well as up to 5 years or more after the conclusion of polychemotherapy. A T1R is clinically characterized by the increase and exacerbation of preexisting lesions with no involvement of the individual's general condition. In a T2R, nerve involvement is less frequent; the individual presents with general malaise, fever, and systemic involvement, which is not restricted only to the skin. Isolated neuritis results in symptoms and neurological signs without the cutaneous manifestations of T1Rs and T2Rs; in the absence of pain, they are called silent neuritis [24]. Approximately $25-50 \%$ of sick individuals can develop reactions [5-8].

Among individuals with borderline leprosy, 30\% show a risk of T1R; the incidence is significantly higher in borderlineborderline and borderline-lepromatous (BL) cases than in borderline tuberculoid cases. In contrast, T2R occurs more frequently in individuals with lepromatous leprosy (LL), affecting $20 \%$ of LL cases and $10 \%$ of BL cases $[9,10]$.

Studies published in the past 5 years have addressed the possible relationship between the occurrence of reactional episodes and dental infections [11-14]. The oral health conditions in individuals with leprosy are poor, that is, high rates of caries and periodontal disease (PD) [15-20], with little involvement of dentists to control these diseases [11, 21].

Leprosy reactions and dental infections have some common characteristics. They are both slowly evolving chronic infections, modulated by a number of inflammatory and immunopathological events resulting from the interaction between bacteria and their products and the host immune 
response. Both the complications of leprosy and extent and severity of PD manifest as secondary damage, arising from an unsuccessful defense mechanism of the host [2224]. Common and important mediators expressed in both conditions include IL-1, IL-1 $\beta$, IL-4, IL-6, IL-8, IL-10, TNF- $\alpha$, and IFN- $\gamma$ [25-29].

The release of cytokines in response to oral bacteria is among the mechanisms underlying the systemic effects of periodontitis [30, 31]. Motta et al. [12-14] investigated the role of dental infections in the triggering, maintenance, or exacerbation of reactive episodes and emphasized the possible role of IL-6, IL-10, and IL-1 in these events. However, there is need for additional studies to understand this possible interaction.

The hypothesis of a close relationship between oral diseases and certain systemic conditions is not new. The scientific evidence in dentistry and medicine has corroborated the bidirectional relationship between an individual's general health and oral health as well as specific oral diseases, such as PDs [32-34].

Considering the scarcity of studies aimed at investigating the relationship between dental infections and leprosy reactions and the possibility of a systemic effect of cytokines in the immunopathological mechanisms of these diseases, this systematic review aimed at analyzing scientific publications reporting the inflammatory mediators involved in the immunopathological processes of dental infections and leprosy reactions.

\section{Materials and Methods}

2.1. Type of Study. This was an exploratory systematic review of the primary literature on inflammatory mediators involved in the immunopathological process of reactional episodes in leprosy and dental infections.

2.2. Data Sources and Time Period. A search of the literature was conducted between January and December 2013 in the following electronic databases: (i) national database (BBO Dental/Brazil, Spanish Bibliographic Index of Health Sciences/IBECS, and Scientific Electronic Library Online/SciELO); (ii) international database (Latin American and Caribbean Health Sciences/LILACS, US National Library of Medicine/PubMed, and U.S. National Library of Medicine's bibliographic database/MedLine); and (iii) the cochrane library.

2.3. Search Strategy and Selection of Articles. Considering that the term "periodontal medicine" was first used in dentistry in 1996 to designate the branch of periodontology addressed to the investigations of the bidirectional relationships between PDs and the general condition of the individual $[33,34]$, we limited the literature search to studies published between January 1, 1996, and December 31, 2013.

The search strategy was constructed with descriptors in English, Spanish, and Portuguese and considering their synonyms, according to the specificities of the databases.
We identified the descriptors in the health sciences by consulting the DeCS according to Keywords in Context and the Medical Subject Headings (MeSH).

The following MeSH terms and keywords were used:

(1) Pulpitis

(2) Gingival diseases, gingivitis.

(3) Periodontitis; periodontal diseases, hierarchical term in $\mathrm{MeSH}$ : aggressive periodontitis; chronic periodontitis; periapical periodontitis; periodontal abscess; periodontal pocket.

(4) Cytokines; interleukin(s) (blood/skin).

(5) Inflammation mediators; biological markers; biomarkers.

(6) Type I reversal reaction; reversal reaction; erythema nodosum leprosum.

(7) Leprosy reaction; leprosy reactions; leprosy reactional.

(8) Biopsy.

(9) Skin.

The search was conducted in three stages. During Stage I, the bibliographic search was conducted for the terms "leprosy reactions" and "cytokines." In Stage II, we used "dental infections" and "cytokines," and, in Stage III, we used "leprosy reactions," "dental infections," and "cytokines."

Studies were included that investigated the participation and involvement of cytokines in the inflammatory process of dental infections and/or during the occurrence of leprosy reactions.

We excluded all articles that had any of the following groups: pregnant women, syndromic individuals, smokers, experimental animals, or individuals with systemic diseases or conditions (diabetes, menopause, cardiovascular disease, and chronic renal failure). We also excluded studies involving cell cultures, influence of drugs, the production of cytokines and periodontopathic bacteria, genetic polymorphisms, mutations, case reports, systematic reviews, literature reviews, and meta-analyses.

After the article selection, we constructed a form with the following pieces of information: author and year, study population (sample size, age, type of dental infection, and/or reactional episode), laboratory techniques used in the studies, cytokines analyzed, and additional relevant results.

Exploratory analyses using tables, figures, and flowcharts were conducted.

\section{Results}

We identified 911 publications dated between January 1, 1996, and December 21, 2013, of which we excluded 795; a further 37 articles were duplicates. We selected the remaining 79 publications for analysis: 10 articles (12.7\%) in Stage I, 68 articles $(86.0 \%)$ in Stage II, and 1 article $(1.3 \%)$ in Stage III. In these articles of dental infections and the occurrence of reactional episodes, the 27 researched inflammatory mediators, independent of the laboratory technique and type of sample, 


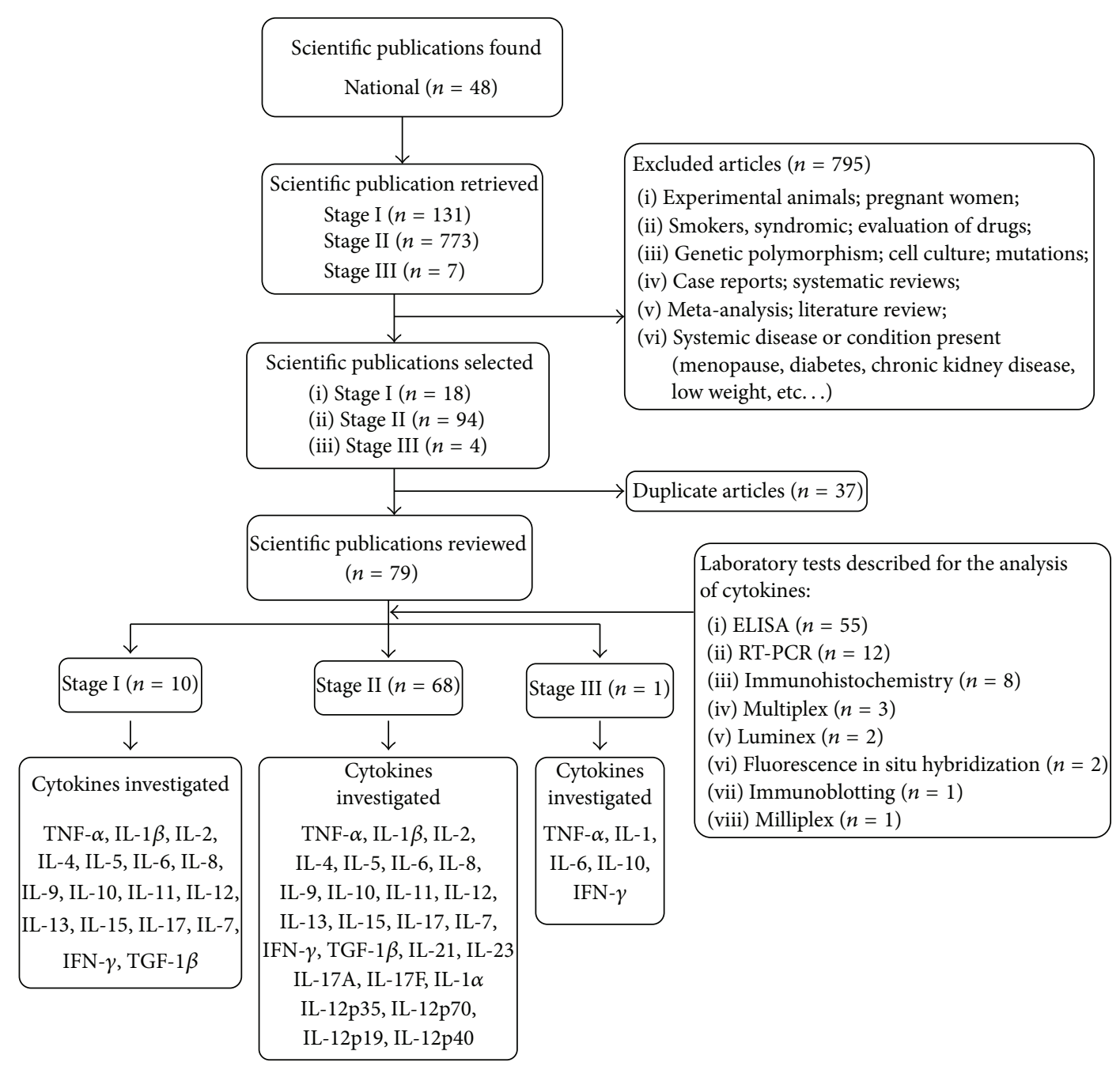

FIGURE 1: Flowchart of the selection of scientific articles published between January 1, 1996, and December 31, 2013, regarding inflammatory mediators involved in leprosy reactional episodes and dental infections. Stage I (bibliographic search for inflammatory mediators/leprosy reactions); Stage II (bibliographic search for inflammatory mediators/dental infections); Stage III (bibliographic search for inflammatory mediators/dental infections/leprosy reactions).

were TNF- $\alpha$, IFN- $\gamma$, IL-1/IL-1 $\beta$, IL-1 $\alpha$, IL-2, IL-4, IL-5, IL-6, IL-7, IL-8, IL-9, IL-10, IL-11, IL-12, IL-13, IL-12p35, IL-12p70, IL-12p40, IL-15, IL-17, IL-17A, IL-17F, IL-18, IL-21, IL-23, IL-23 p19, and TGF-1 $\beta$ (Figure 1).

The use of ELISA (69\%) and RT-PCR (15\%) to detect the inflammatory mediators was more frequently reported (Figure 1).

Among the studies on dental infection, the most common proinflammatory mediators were IL-1 $\beta$ ( 29 articles), TNF- $\alpha$ (25 articles), IL-6 (24 articles), and IFN- $\gamma$ (17 articles), and the most common anti-inflammatory mediator was IL-4 (15 articles). For leprosy reactions, the most common proinflammatory mediators were TNF- $\alpha$ ( 7 articles), IFN $-\gamma$ (5 articles), IL-6 (4 articles), and IL-17 (3 articles), and the most common anti-inflammatory mediators were IL-4 (4 articles) and IL-10 (4 articles) (Table 1).

Of the publications regarding the role of inflammatory mediators in the immunopathological process of dental infections, $10 \%$ were associated with periapical lesions (e.g., cyst, periapical granuloma, keratocyst, chronic periapical lesion, radicular cyst, and periapical lesion), 10\% were associated with the presence of severe caries and/or pulpitis, and 79\% referred to $\mathrm{PD}$.

Of the 19 studies that analyzed the participation of inflammatory mediators in PD, defined as mild, moderate, or severe, or whose definition parameters included only measurements of the periodontal pocket depth, clinical attachment loss, and presence of gingival bleeding, inflammatory mediators were correlated with the clinical parameters of PD. The following cytokines were included in these articles: TNF- $\alpha$, IL- $1 \beta$, IL-2, IL-4, IL-6, IL-8, IL-10, IL-11, IL-13, IL-17, IL-18, IL-23, IFN- $\gamma$, and IL-12p35 (Table 2).

Laboratory analyses of inflammatory mediators were conducted in serum (11 articles), gingival, pulp, or periapical tissue biopsy (28 articles), and gingival crevicular fluid (GCF) or saliva (29 articles). Only one article presented the analysis of inflammatory mediators in plasma (Table 2). 


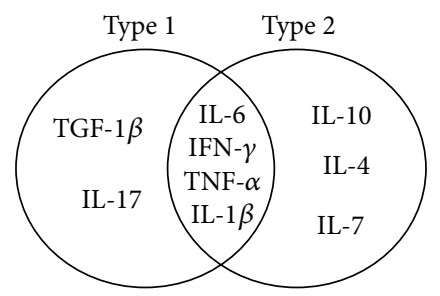

(a) Leprosy reaction

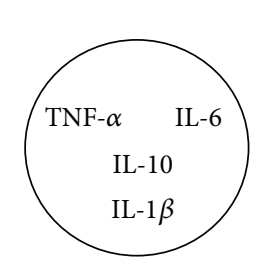

(1b) Periapical lesions

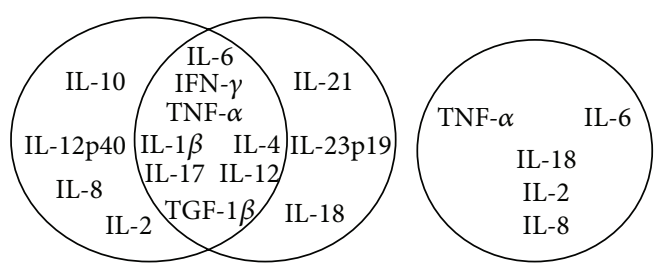

(2b) Periodontal disease Aggressive Chronic (3b) Severe caries and/or pulpitis

(b) Dental infections

Figure 2: Main inflammatory meditators identified for leprosy reaction (a) and dental infections (b) in articles published between January 1, 1996, and December 1, 2013, and selected for the systematic review.

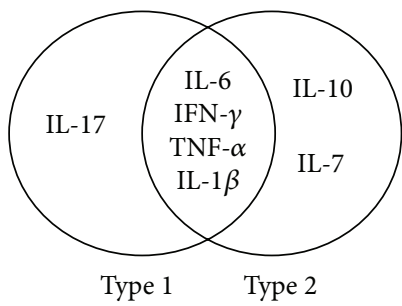

(a) Leprosy reaction

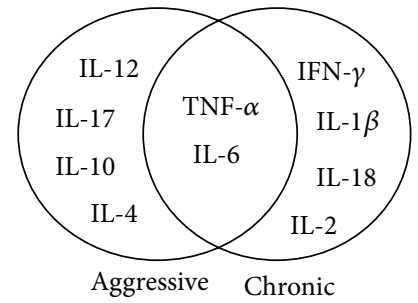

(b) Periodontal disease

Figure 3: Main serum inflammatory mediators that were identified in leprosy reactions and periodontal diseases, by type, in the articles published between January 1, 1996, and December 31, 2013, that were selected for the systematic review.

Only one publication investigated the role of mediators during reactional episodes in individuals with dental infections. We identified higher serum IL-1, IL-6, and IL-10 levels in individuals with leprosy and dental infection compared with individuals with leprosy without dental infection (Table 3).

Among the articles of leprosy reactions, regardless of the type of sample, IFN- $\gamma$, TNF- $\alpha$, IL- 6 , and IL- $1 \beta$ were involved in T1Rs and T2Rs. In addition, IL-17 and TGF- $\beta 1$ were involved in T1Rs, and the anti-inflammatory mediators IL-10, IL-4, and IL-7 were involved in T2Rs (Figure 2(a)).

IL- 6 and TNF- $\alpha$ were involved in the immunopathological process of dental infections (Figure 2(b)), which included periapical lesions (Figure 2(b)(1b)), PD (Figure 2(b)(2b)), and severe caries and/or pulpitis (Figure 2(b)(3b)). In studies of aggressive periodontitis (PDag) and chronic PD (CPD), 6 proinflammatory mediators (IL-1 $\beta$, IL-6, IFN- $\gamma$, TNF- $\alpha$, IL17 , and IL-12) and 2 common anti-inflammatory mediators (TGF- $\beta$ and IL-4) were involved.

Among the common proinflammatory mediators identified in serum during the occurrence of leprosy reactions (a) and PD (b), IL-6 and TNF- $\alpha$ were predominant (Figure 3).
In the immune process of T2Rs, only the antiinflammatory mediators IL-10 and IL-7 were present in serum. During the occurrence of T1Rs and T2Rs, the proinflammatory mediators IL-6, IFN- $\gamma$, TNF- $\alpha$, and IL- $1 \beta$ were detected. IL-17 participated during the occurrence of T1Rs (Figure 3).

In CPD, we also identified IL- $\beta 1$, IFN- $\gamma$, IL-18, and IL2 as the proinflammatory mediators in serum. The antiinflammatory mediators IL-4 and IL-10 were only identified in serum for PDag. For T2Rs and CPD, the common serum proinflammatory mediators included IL-6, IFN- $\gamma$, TNF- $\alpha$, and IL- $\beta 1$ (Figure 3 ).

\section{Discussion}

In this systematic review, we identified important pro- and anti-inflammatory mediators involved in the occurrence of dental infections and leprosy reactions, including IL-6, IFN- $\gamma$, TNF- $\alpha$, IL-1 $\beta$, IL-17, IL-10, and IL-4, which were independent of the laboratory technique and sample. In serum, significant concentrations of IL- 6 and TNF- $\alpha$ were present during the evolution of periodontitis and reactional 
TABLE 1: Frequency of articles published between January 1, 1996, and December 31,2013, that were selected for the systematic review regarding dental infections, leprosy reactions, and the types of investigated inflammatory mediators.

\begin{tabular}{|c|c|c|c|c|}
\hline \multirow{3}{*}{$\begin{array}{l}\text { Inflammatory } \\
\text { mediators }\end{array}$} & \multicolumn{4}{|c|}{ Type of article } \\
\hline & \multicolumn{2}{|c|}{ Dental infections } & \multicolumn{2}{|c|}{ Leprosy reactions } \\
\hline & $n=68^{*}$ & $\%$ & $n=10^{* *}$ & $\%$ \\
\hline IL- $1 \beta$ & 29 & 42.7 & 3 & 30.0 \\
\hline TNF- $\alpha$ & 25 & 36.8 & 7 & 70.0 \\
\hline IL-6 & 24 & 35.3 & 4 & 40.0 \\
\hline IFN- $\gamma$ & 17 & 25.0 & 5 & 50.0 \\
\hline IL-4 & 15 & 22.0 & 4 & 40.0 \\
\hline IL-10 & 13 & 19.1 & 4 & 40.0 \\
\hline IL-17 $7^{\S}$ & 13 & 19.1 & 3 & 30.0 \\
\hline IL-8 & 12 & 17.6 & 2 & 20.0 \\
\hline IL-2 & 11 & 16.2 & 1 & 10.0 \\
\hline IL-12 & 6 & 8.8 & 2 & 20.0 \\
\hline IL- $1 \alpha$ & 6 & 8.8 & & \\
\hline IL-18 & 5 & 7.3 & & \\
\hline IL-23 & 4 & 5.9 & & \\
\hline IL-5 & 4 & 5.9 & 2 & 20.0 \\
\hline IL-11 & 4 & 5.9 & & \\
\hline TGF-1 $\beta$ & 4 & 5.9 & 1 & 10.0 \\
\hline IL-13 & 4 & 5.9 & 1 & 10.0 \\
\hline IL-15 & 3 & 4.4 & 1 & 10.0 \\
\hline IL-7 & 2 & 2.9 & 1 & 10.0 \\
\hline IL-12p40 & 2 & 2.9 & & \\
\hline IL-12p70 & 2 & 2.9 & & \\
\hline IL-23p19 & 2 & 2.9 & & \\
\hline IL-9 & 1 & 1.5 & 1 & 11.1 \\
\hline IL-12p35 & 1 & 1.5 & & \\
\hline IL-21 & 1 & 1.5 & & \\
\hline
\end{tabular}

${ }^{*}$ Number of articles about dental infections.

${ }^{* *}$ Number of articles about leprosy reactions.

${ }^{\S}$ Included in the cytokines IL-17A and IL-17F.

lesions, while IFN- $\gamma$ and IL- $1 \beta$ were related with T1R, T2R, and CPD.

Such inflammatory mediators are produced by a wide variety of cells during the acute and chronic phases of inflammation, and they have important modulatory and regulatory functions in the inflammatory responses of the immune system. They function together to create a complex network with redundant, synergistic, or antagonistic properties. Furthermore, some molecules are pleiotropic and may have endocrine activity, such as IL- 6 , TNF- $\alpha$, and IL- $1 \beta$ $[35,36]$.

4.1. IL-6. IL-6 is mainly synthesized in the presence of IL-1, TNF- $\alpha$, and lipopolysaccharides that are present in the cell walls of gram-negative bacteria, including the periodontopathogens. It is multifunctional and is present in both the innate and adaptive immune responses, with a key role in the acute immune inflammatory response. It stimulates the T lymphocytes, contributes to the increase of B lymphocytes, and contributes to the production of antibodies in the Th2cell-mediated immune response $[10,26,37,38]$.

IL- 6 and TNF- $\alpha$ have been found in biopsy specimens of all individuals with T1R or T2R [39], who have also demonstrated increased levels of IL-6 in serum $[26,40]$. Considering its proinflammatory potential and ability to stimulate the production of antibodies, some authors have suggested this cytokine as a valuable prognostic marker for leprosy reactions $[7,9,36,37,40,41]$.

In more recent studies, an association between increased plasma IL-6 levels and the occurrence of T1R and T2R has been reported. In T1R, this condition can be explained by the probable participation of cells related to the T1 type response, resulting from nongenetic and/or genetic determinants. In contrast, in $\mathrm{T} 2 \mathrm{R}$, the main determinant for the significant increase in IL- 6 seems to be the presence of polymorphisms in the encoding gene of this cytokine $[7,41]$.

In the present review, regardless of the type of sample used, IL- 6 in dental infections was associated with the presence of severe caries, symptomatic periapical lesions, and PD status. As osteoclast-activating factors, IL-6, TNF- $\alpha$, and IL- $1 \beta$ are involved in bone resorption during the evolution of PDs [42-50]. IL-6 was correlated with the probing depth and sulcus impairment; it was identified in biopsy specimens, saliva, and gingival fluid, in addition to serum and plasma [42, 43, 46, 47, 49-52]. Individuals with CPD in advanced stages, severe periodontitis, or PDag had significant IL-6 levels [42, 49-51]. The presence of polymorphic variants in the IL-6 gene has indicated an association with the pathogenesis of CPD [53], as well as an increased risk for PDag [54]. Interestingly, this polymorphism seems to have a similar location as that of SNP rs1800795, which is associated with T2R [41].

According to Motta et al. [12], IL-6 is among the mediators possibly involved in the maintenance of reactional episodes, in addition to serum IL-1 and IL-10. Multibacillary individuals with oral infections showed a greater risk for reactions, especially of the erythema nodosum leprosum type, with a clinical improvement of reactional episodes after dental therapy $[12,13,55]$. Recently, it was also observed that dental infections in individuals with leprosy could increase the proinflammatory response mediated by IFN- $\gamma$, while the opposite effect occurred for the immunoregulatory activity of IL-4, resulting in exacerbation of the inflammatory reaction [14].

4.2. IFN- $\gamma$. Serum IFN- $\gamma$ levels during the occurrence of T1R, $\mathrm{T} 2 \mathrm{R}$, and CPD favor the phagocytic activity in inflammation and amplify the response activity of T cells. It has also been observed in gingival tissue biopsies from lesions of patients with leprosy, saliva, and GCF [43, 45, 49, 50, 56-60]; it is secreted by CD4+ T cells, CD8+ lymphocytes, peripheral blood mononuclear cells, and natural killer (NK) cells, which are also related to periodontal bone loss [14, 26, 61, 62].

High serum IFN- $\gamma$ levels during the reactivation or in excessive acute immune inflammatory responses during the occurrence of reactional episodes have been discussed in 
TABLE 2: Articles selected for the systematic review on dental infections and the presence of inflammatory mediators in serum (a), biopsy specimens (b), and gingival crevicular fluid (GCF) (c) according to the publication year, author, type of sample, and obtained results.

\begin{tabular}{|c|c|c|c|}
\hline Year & Authors & $N$ & Significant results \\
\hline \multicolumn{4}{|c|}{ (a) Dental infections and Presence of mediators in serum } \\
\hline \multirow{4}{*}{2011} & Kinney et al. ${ }^{*}[105]$ & $83(\mathrm{PD})$ & IL-1 $\beta$, MMP-8, and MMP-9 were strongly correlated with PD status. \\
\hline & Özçaka et al. ${ }^{*}[106]$ & $22(\mathrm{CPD}), 21(\mathrm{C})$ & Individuals with CPD had lower IL-17 levels in saliva. \\
\hline & Robati et al. [51] & $\begin{array}{l}25 \text { (PDagG) } \\
25(\mathrm{C})\end{array}$ & $\begin{array}{l}\text { Low levels of IL- } 4 \text { were associated with PDagG, and IL- } 6 \text { levels were } \\
\text { high compared with the control group. }\end{array}$ \\
\hline & $\begin{array}{l}\text { Sánchez-Hernández et } \\
\text { al. }^{* *}[35]\end{array}$ & $\begin{array}{l}18 \text { (CPD) } \\
12 \text { (PDag) } \\
\quad 9(\mathrm{C})\end{array}$ & $\begin{array}{l}\text { Individuals with PDag had higher IL-12 levels in gingival tissue and } \\
\text { serum. Those with CPD had higher serum IL-18 concentrations than } \\
\text { controls. }\end{array}$ \\
\hline \multirow[b]{2}{*}{2010} & Duarte et al. [70] & $\begin{array}{c}14(\mathrm{PDagG}) \\
14(\mathrm{CPDg}) ; 14(\mathrm{C})\end{array}$ & $\begin{array}{l}\text { After periodontal treatment, the serum TNF- } \alpha \text { concentration } \\
\text { remained high in the PDagG group }\end{array}$ \\
\hline & Schenkein et al. [73] & $\begin{array}{l}53 \text { (PDagL) } \\
49 \text { (PDagG) } \\
67(\mathrm{C})\end{array}$ & $\begin{array}{l}\text { IL-17 was associated with the loss of clinical insertion. Individuals } \\
\text { with PDagG or PDagL had higher serum IL-17 concentrations. }\end{array}$ \\
\hline \multirow[b]{2}{*}{2008} & Abdolsamadi et al. [107] & $\begin{array}{l}40(\mathrm{LPC}) \\
40(\mathrm{C})\end{array}$ & \multirow{2}{*}{$\begin{array}{l}\text { Production of IL- } 6 \text { in LPC could be used as a marker of chronic apical } \\
\text { periodontitis. } \\
\text { Serum levels of RANTES, MIG, and eotaxin differed between healthy } \\
\text { individuals and those with periodontitis. }\end{array}$} \\
\hline & de Queiroz et al. [108] & 17 (CPD), $8(\mathrm{C})$ & \\
\hline 2005 & Bretz et al. $^{* * *}[42]$ & $\begin{array}{l}1131 \text { (severe, moderate, or } \\
\text { absent disease) }\end{array}$ & $\begin{array}{l}\text { High levels of plasma TNF- } \alpha \text { were associated with the extent of PD } \\
\text { and number of teeth. IL- } 6 \text { levels were higher in individuals with more } \\
\text { extensive PD than in other individuals. }\end{array}$ \\
\hline 2003 & Górska et al. $^{* *}[56]$ & $\begin{array}{l}25(\mathrm{CPD}) \\
25(\mathrm{C})\end{array}$ & $\begin{array}{l}\text { Serum and gingival tissue biopsy specimens of individuals with CPD } \\
\text { had higher levels of IL- } 1 \beta \text {, TNF- } \alpha \text {, IL- } 2 \text {, and IFN- } \gamma \text { than those of the } \\
\text { control group. }\end{array}$ \\
\hline 2001 & Murata et al. [52] & 276 individuals & $\begin{array}{l}\text { The severity of PD was not associated with the average serum IL-6 } \\
\text { concentration. Further, } 54 \% \text { were positive for IL- } 6 \text { in serum. }\end{array}$ \\
\hline \multicolumn{4}{|c|}{ (b) Dental infections and presence of inflammatory mediators in biopsy specimens } \\
\hline 2012 & Dutzan et al. [80] & $\begin{array}{l}10(\mathrm{CPD}) \\
\quad 8(\mathrm{C})\end{array}$ & $\begin{array}{l}\text { Individuals with CPD showed increased expression of IL-21, IL-1 } \beta \text {, } \\
\text { IL-6, IL-17, and IL-23p19 and decreased expression of IL-10 and } \\
\text { TGF- } \beta 1 \text {. }\end{array}$ \\
\hline \multirow[b]{2}{*}{2011} & Dutzan et al. ${ }^{\dagger}[109]$ & 15 (CPD), 19 (C) & $\begin{array}{l}\text { Individuals with CPD had higher IL-21 levels in gingival tissue and } \\
\text { GCF than controls. }\end{array}$ \\
\hline & Santos [57] & 36 (DGC), 31 (CPD), 15 (C) & $\begin{array}{l}\text { IFN- } \gamma \text { was present in the gingival tissue of all samples and was } \\
\text { present at higher concentrations in more advanced stages. }\end{array}$ \\
\hline \multirow{3}{*}{2009} & Dutzan et al. $^{\dagger}[58]$ & $\begin{array}{l}106 \text { (moderate or advanced } \\
\text { CPD), } 25 \text { active sites; } 25 \\
\text { inactive sites }\end{array}$ & $\begin{array}{l}\text { The IFN- } \gamma \text { level in gingival fluid was higher than at the active site. } \\
\text { Progressive periodontal lesions in individuals with CPD had higher } \\
\text { expression of IFN- } \gamma \text { and had more frequent IFN- } \gamma \text { expression. }\end{array}$ \\
\hline & Fukada et al. [110] & $\begin{array}{l}20(\mathrm{GP}) \\
10 \text { (cysts), } 8(\mathrm{C})\end{array}$ & $\begin{array}{l}\text { Granulomatous tissue showed increased expression of IL-10, whereas } \\
\text { periapical tissue with granuloma and cyst had similar expressions of } \\
\text { IFN- } \gamma \text { and IL- } 4 \text {. }\end{array}$ \\
\hline & Ohyama et al. [74] & $\begin{array}{l}15(\mathrm{PD}) \\
11(\mathrm{C})\end{array}$ & $\begin{array}{l}\text { Individuals with PD had higher levels of IL- } 23 \text { and IL-12 in } \\
\text { periodontal lesions than the control group. }\end{array}$ \\
\hline \multirow[b]{2}{*}{2008} & Honda et al. [75] & $\begin{array}{c}24(\mathrm{PD}) \\
23(\mathrm{G})\end{array}$ & $\begin{array}{l}\text { Expression of IL-17A mRNA was higher than that of IL-17F mRNA. } \\
\text { The expression of IL-17A differed in gingivitis and periodontitis. }\end{array}$ \\
\hline & Menezes et al. [85] & $\begin{array}{c}57(\mathrm{GP}) \\
38(\mathrm{C}) \\
\end{array}$ & $\begin{array}{l}\text { Periapical granulomas showed higher TNF- } \alpha \text {, IL-10, and RANKL } \\
\text { mRNA expression than healthy periodontal tissues. }\end{array}$ \\
\hline \multirow{4}{*}{2007} & Johnson and Serio [43] & $\begin{array}{l}59(\mathrm{BP}=3 \mathrm{~mm} \text { and } \mathrm{SG}) \\
73(\mathrm{BP}=4-6 \mathrm{~mm}) \\
53(\mathrm{BP}>6 \mathrm{~mm}) \\
58(\mathrm{C})\end{array}$ & $\begin{array}{l}\text { Affected gingival tissue }(3-6 \mathrm{~mm}) \text { showed higher concentrations of } \\
\text { IFN- } \gamma \text {, IL-2, IL- } 4 \text {, IL- } 6 \text {, IL-10, and IL-13 than controls. IL- } 6 \text { showed a } \\
\text { positive correlation with sulcular impairment. }\end{array}$ \\
\hline & Jurisic et al. [86] & $\begin{array}{l}43 \text { (CR), } 15 \text { (keratocysts) } \\
6 \text { (reversible pulpitis) }\end{array}$ & $\begin{array}{l}\text { A higher concentration of TNF- } \alpha \text { was observed in radicular cysts. } \\
\text { The increase in TNF- } \alpha \text { gene expression was associated with }\end{array}$ \\
\hline & Kokkas et al. [44] & $\begin{array}{l}6 \text { (irreversible pulpitis), } 6 \\
\text { (C) }\end{array}$ & $\begin{array}{l}\text { irreversible pulpitis compared with the control group. TNF- } \alpha \text { was } \\
\text { positively associated with the severity of clinical parameters. }\end{array}$ \\
\hline & Brekalo Pršo et al. [87] & $\begin{array}{l}\text { Group I: } 15 \text { (sensitive LP), } \\
\text { Group II: } 15 \text { (insensitive } \\
\text { LP), } 15 \text { (C) }\end{array}$ & $\begin{array}{l}\text { Groups I and II had higher levels of TNF- } \alpha \text {. Symptomatic periapical } \\
\text { tissues had higher levels of IL- } 6 \text { than asymptomatic periapical tissues } \\
\text { and controls. }\end{array}$ \\
\hline
\end{tabular}


TABLe 2: Continued.

\begin{tabular}{|c|c|c|c|}
\hline Year & Authors & $N$ & Significant results \\
\hline 2006 & Honda et al. [59] & $\begin{array}{l}25(\mathrm{CPD}) \\
23(\mathrm{G})\end{array}$ & $\begin{array}{l}\text { Individuals with periodontitis had higher levels of IL- } 1 \beta \text {, IFN- } \gamma \text {, } \\
\text { RANKL, HSP } 60 \text {, and TGF- } \beta 1 \text {. The levels of IL- } 4 \text { were slightly higher } \\
\text { in periodontitis than in gingivitis. }\end{array}$ \\
\hline \multirow[t]{2}{*}{2005} & Johnson and Serio [45] & $\begin{array}{l}36(\mathrm{BP}=3 \mathrm{~mm} \text { and } \mathrm{SG}) \\
39(\mathrm{BP} 4-6 \mathrm{~mm}) \\
15(\mathrm{BP}>6 \mathrm{~mm}) \\
42(\mathrm{C})\end{array}$ & $\begin{array}{l}\text { Concentrations of IL-2, IL- } 4 \text {, IL- } 6 \text {, IL-10, IL-18, and IFN- } \gamma \text { were } \\
\text { higher in biopsy specimens from tissue adjacent to BP of } 4-6 \mathrm{~mm} \\
\text { than in controls. Higher concentrations of IL- } 6 \text { and IL- } 18 \text { were noted } \\
\text { adjacent to sites with a probing depth }>6 \mathrm{~mm} \text { than in healthy sites. }\end{array}$ \\
\hline & $\begin{array}{l}\text { Rodríguez and López } \\
\text { [46] }\end{array}$ & $\begin{array}{c}13(\mathrm{G}), 9(\mathrm{CPD}) \\
13(\mathrm{C})\end{array}$ & $\begin{array}{l}\text { Individuals with gingivitis and periodontitis had higher } \\
\text { concentrations of IL- } 6 \text { in gingival tissues than in healthy tissues. }\end{array}$ \\
\hline 2004 & Johnson et al. [47] & $\begin{array}{c}19(\mathrm{BP}=3 \mathrm{~mm} \text { and } \mathrm{SG}) \\
24(\mathrm{BP} 4-5 \mathrm{~mm}) \\
11(\mathrm{BP} \geq 6 \mathrm{~mm}) \\
31(\mathrm{C})\end{array}$ & $\begin{array}{l}\text { IL- } 6 \text { concentration increased with probing depth; the IL-11 } \\
\text { concentration was higher around } \mathrm{BP}=3 \mathrm{~mm} \text {, and the IL- } 17 \\
\text { concentration was higher around } \mathrm{BP} \text { of } 4-5 \mathrm{~mm} \text { compared with the } \\
\text { other sites. }\end{array}$ \\
\hline 2003 & Zehnder et al. [111] & $\begin{array}{c}11 \text { (severe caries, } \\
\text { symptomatic), } 13(\mathrm{C})\end{array}$ & $\begin{array}{l}\text { Teeth with severe caries showed a higher expression of IL-6, IL-8, and } \\
\text { IL-18. }\end{array}$ \\
\hline 2002 & Pezelj-Ribaric et al. [112] & $\begin{array}{l}20 \text { (irreversible pulpitis) } \\
20 \text { (extensive caries } \\
\text { restoration), } 20(\mathrm{C})\end{array}$ & $\begin{array}{l}\text { Teeth with irreversible pulpitis showed higher concentrations of } \\
\text { TNF- } \alpha \text { than controls. }\end{array}$ \\
\hline 2001 & Lappin et al. [60] & $\begin{array}{c}10(\mathrm{PIP}) \\
10(\mathrm{CPD})\end{array}$ & $\begin{array}{l}\text { IFN- } \gamma \text { and IL- } 2 \text { were involved in disease progression, suggesting a } \\
\text { modulator role in the inflammatory response. }\end{array}$ \\
\hline 2000 & Danin et al. [113] & $25(\mathrm{LPC})$ & TGF- $\beta$ per mg tissue was correlated with the diameter of the lesions. \\
\hline \multirow[b]{2}{*}{1999} & Barkhordar et al. [114] & $\begin{array}{c}6 \text { (pulpitis), } 6(\mathrm{LP}) \\
8(\mathrm{C})\end{array}$ & $\begin{array}{l}\text { Samples of the periapical and inflamed pulp tissue showed medium } \\
\text { levels of IL-6, which were higher compared with control levels. }\end{array}$ \\
\hline & Huang et al. [115] & $\begin{array}{l}\text { Teeth (irreversible pulpitis } \\
\text { and C) }\end{array}$ & $\begin{array}{l}\text { Teeth with irreversible pulpitis had higher levels of IL- } 8 \text { than those } \\
\text { with healthy pulp. }\end{array}$ \\
\hline \multirow[t]{2}{*}{1998} & McGee et al. [48] & $\begin{array}{c}N=8 \\
n_{\mathrm{I}}: \mathrm{BP} \leq 3 \mathrm{~mm} \\
n_{\mathrm{II}}: \mathrm{BP} \text { with } 4-6 \mathrm{~mm} \\
n_{\mathrm{III}}: \mathrm{BP}>6 \mathrm{~mm}\end{array}$ & $\begin{array}{l}\text { There was a higher concentration of IL- } 8 \text { around } \mathrm{BP} \leq 3 \mathrm{~mm} \text { and a } \\
\text { higher concentration of IL- } 6 \text { and IL- } 1 \beta \text { around } \mathrm{BP}>6 \mathrm{~mm} \text {. }\end{array}$ \\
\hline & Shimauchi et al. [81] & $\begin{array}{l}29 \text { teeth with pulp exudates } \\
\text { (EP) (symptomatic and } \\
\text { asymptomatic) }\end{array}$ & $\begin{array}{l}\text { There was a positive correlation between IL-1ra and IL- } 1 \beta \text {, at relatively } \\
\text { higher levels of IL-1ra when compared with IL- } 1 \beta \text {. }\end{array}$ \\
\hline \multirow{4}{*}{1997} & Rauschenberger [116] & $\begin{array}{l}12 \text { (irreversible pulpitis), } 17 \\
\text { (C) }\end{array}$ & $\begin{array}{l}\text { IL-2 concentrations differed significantly between inflamed pulp } \\
\text { tissue and healthy pulp tissue. }\end{array}$ \\
\hline & Roberts et al. [117] & $17(\mathrm{CPD})$ & $\begin{array}{l}\text { TNF- } \alpha \text { and IL-1ra mRNA expression were higher in CPD than in } \\
\text { healthy gingival tissue. }\end{array}$ \\
\hline & Roberts et al. [118] & $\begin{array}{l}34(\mathrm{CPD}) \\
5(\mathrm{C})\end{array}$ & $\begin{array}{l}\text { TNF- } \alpha \text { mRNA expression was higher in CPD than in controls. IL- } 1 \beta \text {, } \\
\text { IL-1ra, and IL- } 1 \alpha \text { were seen more often in healthy tissue. }\end{array}$ \\
\hline & Tokoro et al. [89] & $\begin{array}{l}13 \text { (moderate or advanced } \\
(\mathrm{PD}), 5(\mathrm{G})\end{array}$ & $\begin{array}{l}\text { Gingival tissue with periodontitis showed a predominant expression } \\
\text { of IL- } 4 \text { and IL- } 5 \text {. There was a predominance of IL- } 1 \alpha \text {, IL- } 1 \beta \text {, and } \\
\text { TNF- } \alpha \text { in gingivitis. }\end{array}$ \\
\hline \multicolumn{4}{|c|}{ (c) Dental infections and presence of inflammatory mediators in GCF and saliva } \\
\hline \multirow{3}{*}{2013} & Ertugrul et al. [90] & $\begin{array}{c}21(\mathrm{PDagG}) \\
21(\mathrm{CPD}) \\
21(\mathrm{G}), 21(\mathrm{C})\end{array}$ & $\begin{array}{l}\text { PDagG had higher total levels of IL- } 8 \text { in GCF than CPD, G, and } \\
\text { controls. Levels of IL-1 } \beta \text { and TNF- } \alpha \text { were higher for the group with } \\
\text { PDagG. }\end{array}$ \\
\hline & Rathnayake et al. [82] & $441(\mathrm{PD})$ & $\begin{array}{l}\text { IL- } 1 \beta \text { can be used as a marker in PD. Individuals with severe } \\
\text { periodontitis showed a higher concentration of IL- } 1 \beta \text {. }\end{array}$ \\
\hline & Yue et al. [49] & $\begin{array}{l}40 \text { (PDag) } \\
40(\mathrm{C})\end{array}$ & $\begin{array}{l}\text { In PDag, there were higher concentrations of IL- } 1 \beta \text {, IL-2, IL- } 6 \text {, IFN- } \gamma \text {, } \\
\text { and TNF- } \alpha \text { in saliva and GCF. }\end{array}$ \\
\hline 2012 & Ay et al. [119] & $\begin{array}{l}20 \text { (PDagG), } \\
18(\mathrm{C})\end{array}$ & $\begin{array}{l}\text { The frequency of IL-11 was lower in the group with PDagG, and the } \\
\text { concentration of IL-17 was lower than in the control group. }\end{array}$ \\
\hline \multirow{5}{*}{2011} & Chaudhari et al. [95] & $\begin{array}{l}30(\mathrm{CPD}) \\
30(\mathrm{C})\end{array}$ & $\begin{array}{l}\text { IL-1 } \beta \text { was positively correlated with the following clinical parameters: } \\
\text { bleeding on probing, pocket depth, periodontal disease rating, and } \\
\text { tooth mobility. }\end{array}$ \\
\hline & Garrido Flores et al. [88] & $\begin{array}{l}14 \text { (PAA) } \\
14(\mathrm{C})\end{array}$ & $\begin{array}{l}\text { Higher TNF } \alpha \text { concentrations were noted in gingival sites of teeth } \\
\text { with PAA than in the control group. }\end{array}$ \\
\hline & Kaushik et al. [83] & $28(\mathrm{CPDg}),(\mathrm{C})$ & $\begin{array}{l}\text { Individuals with PD had a medium level of elevated IL- } 1 \beta \text { compared } \\
\text { with the control group. }\end{array}$ \\
\hline & Shaddox et al. [50] & \multirow{2}{*}{$\begin{array}{c}34(\mathrm{PDagL}) \\
9(\mathrm{C}) \\
103\left(\mathrm{PIP}_{1}\right), 42\left(\mathrm{PIP}_{2}\right) \\
45(\mathrm{C})\end{array}$} & $\begin{array}{l}\text { Patients with PDag had higher levels of TNF } \alpha \text {, IFN } \gamma, \text { IL1 } \beta \text {, IL2, IL6, } \\
\text { IL10, and IL12p } 40 \text { than healthy individuals. }\end{array}$ \\
\hline & Stashenko et al. ${ }^{\dagger \dagger}[120]$ & & Levels of IL-1 $\beta$ in GCF increased according to the severity of PD. \\
\hline
\end{tabular}


TABLE 2: Continued.

\begin{tabular}{|c|c|c|c|}
\hline Year & Authors & $N$ & Significant results \\
\hline \multirow{5}{*}{2010} & Burgener et al. [121] & $\begin{array}{c}40 \text { teeth }(\mathrm{PA}) \\
40 \text { teeth }(\mathrm{C})\end{array}$ & $\begin{array}{l}\text { Teeth with apical lesions had higher levels of IL- } 1 \beta \text { in the gingival } \\
\text { fluid than the controls. }\end{array}$ \\
\hline & Fitzsimmons et al. [122] & $\begin{array}{l}430 \text { (moderate or severe } \\
\text { PD), } 509(\mathrm{C})\end{array}$ & $\begin{array}{l}\text { PD was independently associated with higher levels of IL-1 } \beta \text { and } \\
\text { C-reactive protein. }\end{array}$ \\
\hline & Perozini et al. [96] & $\begin{array}{l}12(\mathrm{CPD}), 12(\mathrm{G}) \\
12(\mathrm{C})\end{array}$ & $\begin{array}{l}\text { IL-1 } \beta \text { concentrations were higher in CPD than in the other groups. } \\
\text { IL-1 } \beta \text { levels were positively correlated with PD, the volume of gingival } \\
\text { fluid, and pocket depth. }\end{array}$ \\
\hline & Teles et al. [97] & $\begin{array}{l}20(\mathrm{CPD}) \\
20(\mathrm{C})\end{array}$ & $\begin{array}{l}\text { Clinical parameters (PD, BOP, vol GCF, R, and Sup) were positively } \\
\text { correlated with the levels of IL- } 1 \beta \text { and IL- } 8 \text { in GCF. }\end{array}$ \\
\hline & Teles et al. [98] & $\begin{array}{c}31(\mathrm{PDagG}) \\
25(\mathrm{C}) \\
\end{array}$ & $\begin{array}{l}\text { PDagG had higher average levels of IL-1 } \beta \text {. There was a tendency for } \\
\text { levels of IL- } 2 \text { and IL- } 13 \text { to be higher in PDagG. }\end{array}$ \\
\hline \multirow{5}{*}{2009} & Ay et al. [123] & $\begin{array}{l}40(\mathrm{CPD}): \mathrm{BP} \leq 4 \mathrm{~mm} ; \mathrm{BP} \\
\quad \geq 5 \mathrm{~mm} \\
20(\mathrm{C})\end{array}$ & $\begin{array}{l}\text { The total rate and concentration of IL-11 and IL- } 17 \text { were lower in the } \\
\text { group with } \mathrm{BP} \geq 5 \mathrm{~mm} \text {. }\end{array}$ \\
\hline & Bastos et al. [91] & $\begin{array}{c}14(\mathrm{PDag}) \\
13(\mathrm{C})\end{array}$ & TNF- $\alpha$ concentrations were higher in PDag than in controls. \\
\hline & Fitzsimmons et al. [124] & $\begin{array}{l}511 \text { (moderate or advanced } \\
\text { PD), } \\
562(\mathrm{C})\end{array}$ & $\begin{array}{l}\text { There were higher levels of IL-1 } \beta \text { and PCR in individuals with PD. } \\
\text { Clinical parameters were positively correlated with biomarker levels. }\end{array}$ \\
\hline & Pradeep et al. [71] & $\begin{array}{l}20(\mathrm{CPD}), 20(\mathrm{G}), 20(\mathrm{C}), 3 \\
\text { individuals after treatment }\end{array}$ & $\begin{array}{l}\text { IL-18 levels increased according to the severity of periodontal disease, } \\
\text { decreasing after the treatment. }\end{array}$ \\
\hline & Teles et al. [125] & $\begin{array}{c}74(\mathrm{CPD}) \\
44(\mathrm{C})\end{array}$ & $\begin{array}{l}\text { Mean salivary levels of IL- } 8 \text { were positively correlated with probing } \\
\text { depth and the average percentage of sites with bleeding on probing. }\end{array}$ \\
\hline \multirow{4}{*}{2008} & Frodge et al. [92] & $\begin{array}{l}35(\mathrm{PD}) \\
39(\mathrm{C})\end{array}$ & Individuals with PD had higher levels of TNF- $\alpha$. \\
\hline & $\begin{array}{l}\text { Tóbon-Arroyave et al. } \\
{[126]}\end{array}$ & $\begin{array}{l}30(\mathrm{CPD}) \\
18 \text { (PDag) } \\
18(\mathrm{C})\end{array}$ & $\begin{array}{l}\text { The salivary level of IL- } 1 \beta \text { did not differ between groups with } \\
\text { periodontitis, but it was higher than in the control group. }\end{array}$ \\
\hline & Toker et al. [72] & $\begin{array}{l}15 \text { (PDagG) } \\
15(\mathrm{C})\end{array}$ & $\begin{array}{l}\text { There were higher levels of IL- } 1 \beta \text { in sites with moderate or deep initial } \\
\text { pocket than in the shallow pockets. }\end{array}$ \\
\hline & Yücel et al. [84] & $\begin{array}{l}12(\mathrm{CPD}), 14(\mathrm{G}) \\
14(\mathrm{C})\end{array}$ & $\begin{array}{l}\text { IL- } 1 \beta \text { and IL- } 12 \text { concentrations in GCF were higher in CPD than in } \\
\text { the control group. }\end{array}$ \\
\hline 2007 & Tsai et al. [69] & 17 (CPD) & $\begin{array}{l}\text { Nonsurgical periodontal treatment resulted in a decrease in IFN- } \gamma \\
\text { and an increase in IL- } 4 .\end{array}$ \\
\hline 2006 & Gürkan et al. [127] & $\begin{array}{l}30(\mathrm{PDagG}) \\
32(\mathrm{CPD}), 15(\mathrm{G}) \\
16(\mathrm{C})\end{array}$ & $\begin{array}{l}\text { The rate of TGF- } \beta 1 \text { expression was higher in groups of individuals } \\
\text { with PDagG and CPD than in the control group. }\end{array}$ \\
\hline 2003 & Nicolau et al. [99] & $\begin{array}{c}20(\mathrm{CPD}) \\
20(\mathrm{C})\end{array}$ & $\begin{array}{l}\text { Individuals with CPD showed higher concentrations of IL-1 } \beta \text { in the } \\
\text { gingival fluid compared with the controls. }\end{array}$ \\
\hline 2000 & Guo et al. [128] & $\begin{array}{l}\text { Chronic pulpitis } \\
\text { Acute pulpitis } \\
\text { Control }\end{array}$ & $\begin{array}{l}\text { There were higher IL- } 8 \text { concentrations in teeth with acute pulpitis } \\
\text { than in those with chronic pulpitis. }\end{array}$ \\
\hline 1997 & Ishihara et al. [94] & $\begin{array}{c}\text { (PD) } \\
2(\mathrm{C}) \\
\end{array}$ & $\begin{array}{l}\text { IL- } 1 \beta \text { and IL- } 1 \alpha \text { were associated with the severity of periodontal } \\
\text { disease. }\end{array}$ \\
\hline 1996 & Mathur et al. [93] & $\begin{array}{c}20(\mathrm{PD}) \\
20(\mathrm{C})\end{array}$ & $\begin{array}{l}\text { The average rate and concentration of IL- } 1 \alpha \text { in GCF were higher in } \\
\text { individuals with PD than in controls. The site status is the major } \\
\text { determinant of the cytokine levels in unhealthy sites. }\end{array}$ \\
\hline
\end{tabular}

Note $1 .{ }^{*}$ Analysis in serum and saliva; ${ }^{* *}$ analysis in serum and biopsy specimens; ${ }^{* * *}$ analysis in plasma; ${ }^{\dagger}$ analysis in GCF and biopsy specimens; ${ }^{\dagger \dagger}$ analysis in GCF and serum. PD, periodontal disease; MMP, matrix metalloproteinases; GCF, gingival crevicular fluid; Note 2. CPD, chronic periodontitis; C, control; PDagG, generalized aggressive periodontitis; PDag, aggressive periodontitis; CPDg, generalized chronic periodontitis; PDagL, localized aggressive periodontitis; LPC, chronic apical periodontitis; RANTES, regulated on activation, normal T cell expressed and secreted; MIG, monokine induced by gamma interferon; GP, periapical granuloma; G, gingivitis; RANKL, receptor activator of nuclear factor kappa-B ligand; BP, periodontal pocket; SG, gingival bleeding; CR, radicular cyst; LP, periapical lesion; PIP, early onset periodontitis; EP, pulp exudates; BOP, bleeding on probing; R, recession; Sup, suppuration; PAA, asymptomatic apical periodontitis; PA, periapical periodontitis.

the literature; however, its immunoregulatory mechanisms remain unclear. Verhagen et al. [63], when assessing the change of T-cell subsets in the occurrence of T1R and the profile of secreted cytokines, observed a significant amount of Th0 cells with production of both IFN- $\gamma$ and IL-4. However, individuals with T1R recurrence also showed a bias for Th1 with production of IFN- $\gamma$. In both T1R and, mainly, T2R, there is evidence of the involvement of IFN- $\gamma$ in cellular processes [10, 26, 62, 64-66].

The balance between Th1 and Th2 cells and the change in the serum mediator and skin expression profiles (i.e., IFN- $\gamma$, TNF- $\alpha$, IL-1 $\beta$, IL- 6 , and IL- 4 ), in the occurrence of both T1R 
TABLE 3: Articles selected for the systematic review on leprosy reactions and presence of mediators in skin biopsy and/or serum (a) and leprosy reaction, dental infection, and presence of cytokines (b) according to the publication year, authors, type of sample, and obtained results.

\begin{tabular}{|c|c|c|c|}
\hline Year & Authors & $N$ & Results \\
\hline \multicolumn{4}{|c|}{ (a) Leprosy reaction and presence of inflammatory mediators in skin biopsy specimens and/or serum } \\
\hline 2013 & Abdallah et al. [67] & $\begin{array}{l}31(\mathrm{~L}), 6(\mathrm{~T} 1 \mathrm{R}) \\
6(\mathrm{~T} 2 \mathrm{R}), 43(\mathrm{C})\end{array}$ & $\begin{array}{l}\text { Increased production of IL- } 4 \text { in multibacillary forms can be } \\
\text { responsible for the development of erythema nodosum } \\
\text { leprosum. IL-17 was lower in cases than in controls. }\end{array}$ \\
\hline 2012 & Chaitanya et al. [77] & $\begin{array}{l}80(\mathrm{~T} 1 \mathrm{R}), 21(\mathrm{~T} 2 \mathrm{R}) \\
90(\mathrm{~L}), 94(\mathrm{NL})\end{array}$ & $\begin{array}{l}\text { Serum IL-17 level increased during reactional states. There } \\
\text { was higher elevation during T1R than during T2R and } \\
\text { nonreactional states. }\end{array}$ \\
\hline \multirow{2}{*}{2011} & Lockwood et al. [29] & 299 (tissue) & $\begin{array}{l}\text { TNF- } \alpha \text { and TGF- } 1 \beta \text { were detected in } 78 \% \text { and } 94 \% \text { of the } \\
\text { samples, respectively, and were associated with T1R. }\end{array}$ \\
\hline & Madan et al. [129] & $51(\mathrm{~L}), 10(\mathrm{R})$ & $\begin{array}{l}\text { Levels of IFN- } \gamma \text {, IL- } 1 \beta \text {, and IL-10 were higher in T2R, } \\
\text { whereas the TNF- } \alpha \text { level was higher in T1R. }\end{array}$ \\
\hline 2009 & Stefani et al. [40] & $20(\mathrm{R}), 19(\mathrm{~L})$ & $\begin{array}{l}\text { Potential biomarkers for T1R (CXCL10 and IL-6) and T2R } \\
\text { (IL-6, IL-7, and PDGF-BB) were identified. }\end{array}$ \\
\hline \multirow[t]{2}{*}{2007} & Belgaumkar et al. [26] & $\begin{array}{l}94(\mathrm{~L}), 5(\mathrm{~T} 1 \mathrm{R}) \\
\quad 1(\mathrm{~T} 2 \mathrm{R})\end{array}$ & $\begin{array}{l}\text { Levels of IFN- } \gamma \text { were higher in T1R, whereas the T2R } \\
\text { individuals showed higher levels of IL- } 6 \text { compared to the } \\
\text { nonreactional states. }\end{array}$ \\
\hline & Iyer et al. [130] & $\begin{array}{l}49(\mathrm{R}), 82(\mathrm{~L}) \\
112(\mathrm{NL})\end{array}$ & $\begin{array}{l}\text { IFN- } \gamma \text { showed a greater association with the reactional states, } \\
\text { mainly for T2R. }\end{array}$ \\
\hline 2004 & Faber et al. ${ }^{*}[131]$ & $7(\mathrm{~L})$ & $\begin{array}{l}\text { It was not possible to establish a relationship between the } \\
\text { serum profile of cytokines and T1R. }\end{array}$ \\
\hline 2002 & Teles et al. [39] & 9 (T1R), 16 (T2R) & $\begin{array}{l}\text { TNF- } \alpha \text { and IL- } 6 \text { were detected in all individuals in a } \\
\text { reactional state. }\end{array}$ \\
\hline 1998 & Moubasher et al. [64] & $55(\mathrm{~L}), 35(\mathrm{R})$ & $\begin{array}{l}\text { Individuals with T1R and T2R had higher serum levels of } \\
\text { IFN- } \gamma \text {, TNF- } \alpha \text {, and IL- } 1 \beta \text { than those in a nonreactional state. } \\
\text { Higher levels of IFN- } \gamma \text { and IL- } 6 \text { were noted in T1R and T2R, } \\
\text { respectively. }\end{array}$ \\
\hline \multicolumn{4}{|c|}{ (b) Leprosy reaction, dental infection, and presence of inflammatory mediators in serum } \\
\hline 2010 & Motta et al. [12] & $\begin{array}{l}19(\mathrm{~L} \text { and } \mathrm{OI}) \\
19(\mathrm{~L} \text { without } \mathrm{OI}) \\
10(\mathrm{C}: \mathrm{NL} \text { and } \mathrm{OI})\end{array}$ & $\begin{array}{l}\text { It was observed that } 78.8 \% \text { of individuals with leprosy and OI } \\
\text { presented erythema nodosum and } 15.8 \% \text { presented with a } \\
\text { reverse reaction. Seven days after dental treatment, the serum } \\
\text { levels of IL-1, IL-6, and IL-10 were significantly different } \\
\text { between the groups. The IL- } 6 \text { and IL-10 levels in Group C } \\
\text { were higher than those in the group with L and OI. Clinical } \\
\text { improvement of the reactional episode was noted after dental } \\
\text { treatment in } 68.4 \%(13 / 19) \text { of individuals. }\end{array}$ \\
\hline
\end{tabular}

Note. * Nonsignificant result; L, leprosy; T1R, type 1 reaction; T2R, type 2 reaction; C, control; NL, nonleprosy; R, reaction; OI, oral infection; PDGF-BB, platelet-derived growth factor two B (-BB) chain.

and $\mathrm{T} 2 \mathrm{R}$, seem to be closely related with the clinical spectrum of the disease. Studies show that, in borderline tuberculoid individuals with T1R, the infiltration of LT CD4+ observed in skin and nerve lesions favored by the synergism between IFN$\gamma$ and TNF- $\alpha$ may possibly contribute to the exacerbated cellmediated response, resulting in the elimination of mycobacterial antigens and the development of tissue damage. On the other hand, the immunosuppressive activity of IL- 4 and IL10 , the increase in IFN- $\gamma$ and TNF- $\alpha$, and also the increase in IL- $\beta$, and IL- 6 observed in BL and LL individuals support the evidence of a systemic inflammatory response in the evolution of T2R [26, 61, 62, 64, 65, 67].

With regard to PDs, there is no consensus on the immunological patterns involved in its pathophysiology. In early/stable periodontal lesions (gingivitis), migration of neutrophils of the junctional epithelium to the gingival sulcus and activation of macrophages and T cells are observed, with a predominance of TNF- $\alpha$, IL- 12 , and IFN- $\gamma$, suggesting a cellular response against the pathogens with a Th1 profile and infection control. In advanced/progressive lesions (periodontitis), there are similar proportions of cells with a Th1 profile expressing IFN- $\gamma$ and IL-2 and cells with a Th2 profile expressing IL- 4 and IL- 6 as reported by Berglundh et al. [68], with combined functioning of these cells in chronic periodontitis. The recruitment of B lymphocytes and the production of immunoglobulins strengthen the Th2 profile signaling $[22,36,60]$.

The IFN- $\gamma$ produced by Thl cells in the initial lesion may contribute to infection control by increasing the phagocytic activity of neutrophils and macrophages. When the pathogen or its antigens persist in the dental biofilm, the lesion is not contained. 
On reviewing studies that included biopsies, we found that IFN- $\gamma$ was associated with generalized aggressive periodontitis (PDagG) [50] as well as with advanced stages and periodontal pockets up to $6 \mathrm{~mm}[43,45,57]$. Recently, Yue et al. [49] identified a positive correlation between the presence of IFN $-\gamma$ in saliva and gingival crevicular fluid and the clinical parameters of individuals with PDag. According to Lappin et al. [60], this mediator is involved in the progression of $\mathrm{PD}$, with a decrease in its gingival crevicular fluid levels after nonsurgical therapy [69].

Although the literature review revealed distinct methodologies and values for clinical measures that characterize PDs (e.g., CPD, PDag, and severe and moderate periodontitis), there are concordant results about the influence of dental treatment on the pattern of inflammatory mediators $[12,69-$ 72].

Given the complex interrelation between inflammatory mediators and immune system cells, studies have suggested the participation of other cellular subtypes such as regulatory T cells, Th3 cells (which have a immunosuppressant profile), and Th17 cells (which have a proinflammatory profile) for better understanding periodontal infections [35, 57, 73-76] and the evolution of the infection in leprosy reactional states $[10,62,67,77-79]$.

There is evidence that Th17 cells, once stimulated in PDs, produce a variety of mediators such as IL-17 and TNF- $\alpha$, correlated to the formation of osteoclasts, bone resorption, and loss of clinical attachment. This is associated with CPD and PDag [47, 57, 58, 65, 70, 73-75].

In reactional episodes, IL-17 seems to be involved in the development of T1R $[77,79]$.

4.3. TNF- $\alpha$ and $I L-1 \beta$. As previously described, TNF- $\alpha$ and IL- $1 \beta$ are produced by macrophages mainly activated by lipopolysaccharides in the cell wall of gram-negative bacteria; they are among the main mediators responsible for an acute inflammatory response. These mediators participate in tissue remodeling and bone resorption in addition to stimulating angiogenesis and promoting fibroblast activation. Both mediators were identified in biopsy specimens and serum of individuals with PD during the occurrence of reactional episodes $[12,30,39,40,64]$, whereas TNF- $\alpha$ was detected in saliva and the gingival fluid of individuals with dental infections [12, 40, 56, 80-84].

In dental infections, TNF- $\alpha$ was associated with periapical granulomas [85], radicular cysts [86], acute periapical lesions [87, 88], and, mainly, PDs [42, 49, 50, 56, 70, 89-93].

On the one hand, high serum TNF- $\alpha$ levels were shown to be associated with the extent and severity of disease $[82,94]$ and with the clinical parameters of individuals with PDagG and CPD [42, 49, 70, 90, 91, 95-99]; on the other hand, Tokoro et al. [89] reported high serum TNF- $\alpha$ and IL-1 $\beta$ levels in gingivitis. Even after dental therapy, the TNF- $\alpha$ levels remained high compared to the control group.

On studying the immune pattern in cases of leprosy infection, Foss [61] found an increase in TNF- $\alpha$ production associated with high levels of C-reactive protein, suggesting that TNF- $\alpha$ was involved in the inflammatory reaction of erythema nodosum.
Elevated levels of TNF- $\alpha$, IL-6, and IL- $1 \beta$ in serum and in the lesions of patients with T2R seem to be associated with the clinical manifestations of T2R [9, 100]. Motta et al. [12] suggested that the systemic inflammatory effects triggered by IL- $1 \beta$ in individuals with leprosy and dental infection can also contribute to the triggering of erythema nodosum leprosum. In this review, we found that TNF- $\alpha$ was associated with both T1Rs and T2Rs [30, 39, 40, 64].

The dynamic interaction between the cells of innate and adaptive immunity, the balance between Th1 and Th2 lymphocyte subpopulations, and the presence of molecular mediators and their receptors seem to determine the pattern of the immunological response of PDs and leprosy reactions, controlling or amplifying the inflammatory processes $[26,36$, $70,101]$.

Although most studies considered in this systematic review have used the classification defined by the American Academy of Periodontology, including gingivitis, CPD, and PDag (localized or generalized), there were differences in the definition of periodontitis, the criteria to establish the depth of the periodontal pocket and the loss of clinical attachment, and the age group of the participants. For example, 28\% of the articles described PD as soft, moderate, or severe. Further, some studies had a small sample size for both PDs and leprosy reactions.

According to Buduneli and Kinane [102], the depth of the periodontal pocket and gingival bleeding after probing are the most reliable parameters, not only for diagnosis, as they are key indicators of periodontal tissue destruction, but also for disease prognostication. Some authors suggest that the heterogeneity in the definitions of periodontitis hinders the comparison of results between studies [103, 104]. Based on the literature analyzed, the need for longitudinal studies with better standardization of the population presented and a greater uniformity between techniques and experiments becomes evident. The development of molecular and chemical biomarkers with predictive and prognostic value can help in the early identification of patients at an increased risk of periodontal or leprosy diseases.

In this regard, monitoring of treatment effectiveness and the development of new instruments to monitor these infections would decrease the incidence of neural injuries and disabilities in individuals with leprosy and the early loss of dental function.

In summary, regardless of the laboratory technique used and the type of sample analyzed, the identified proinflammatory mediators involved in the immune pathologic process of dental infections and leprosy reactions, particularly IL-6 and TNF- $\alpha$, were similar in the studies reviewed. Specifically, for leprosy reactions and PDs, IFN- $\gamma$ and IL$\beta-1$ were significant. This pattern was reflected in serum, and the presence of IFN- $\gamma$ and IL- $1 \beta$ was associated with CPD.

\section{Conflict of Interests}

The authors declare that there is no conflict of interests regarding the publication of this paper. 


\section{Acknowledgment}

The paper was supported by Fundação de Amparo à Pesquisa do State de Mato Grosso, Brazil (FAPEMAT), e CNPq (PROCESSO no. 477727/2011).

\section{References}

[1] World Health Organization (WHO), Leprosy Elimination. Leprosy: The Disease, World Health Organization, Geneva, Switzerland, 2013, http://www.who.int/lep/leprosy/en/.

[2] C. Lienhardt and P. E. M. Fine, "Type 1 reaction, neuritis and disability in leprosy: what is the current epidemiological situation?" Leprosy Review, vol. 65, no. 1, pp. 9-33, 1994.

[3] L. D. Monteiro, C. H. M. de Alencar, J. C. Barbosa, K. P. Braga, M. D. de Castro, and J. Heukelbach, "Physical disabilities in leprosy patients after discharge from multidrug therapy in Northern Brazil," Cadernos de Saúde Pública, vol. 29, no. 5, pp. 909-920, 2013.

[4] C. G. N. Voorend and E. B. Post, "A systematic review on the epidemiological data of erythema nodosum leprosum, a type 2 leprosy reaction," PLoS Neglected Tropical Diseases, vol. 7, no. 10, Article ID e2440, 2013.

[5] L. W. F. Souza, "Leprosy reactions in discharged patients following cure by multidrug therapy," Revista da Sociedade Brasileira de Medicina Tropical, vol. 43, no. 6, pp. 737-739, 2010.

[6] J. R. Antonio, R. M. Soubhia, V. D. Paschoal et al., "Epidemiological study of reactions and physical disabilities in leprosy patients in São José do Rio Preto," Arquivos de Ciências da Saúde, vol. 18, pp. 9-14, 2011.

[7] V. Fava, M. Orlova, A. Cobat, A. Alcaïs, M. Mira, and E. Schurr, "Genetics of leprosy reactions: an overview," Memorias do Instituto Oswaldo Cruz, vol. 107, no. 1, pp. 132-142, 2012.

[8] D. E. Antunes, S. Araujo, G. P. Ferreira et al., "Identification of clinical, epidemiological and laboratory risk factors for leprosy reactions during and after multidrug therapy," Memorias do Instituto Oswaldo Cruz, vol. 108, no. 7, pp. 901-908, 2013.

[9] R. M. Bhat and C. Prakash, "Leprosy: an overview of pathophysiology," Interdisciplinary Perspectives on Infectious Diseases, vol. 2012, Article ID 181089, 6 pages, 2012.

[10] Y. Degang, K. Nakamura, T. Akama et al., "Leprosy as a model of immunity," Future Microbiology, vol. 9, no. 1, pp. 43-54, 2014.

[11] D. C. Cortela and E. Ignotti, A hanseníase e o cirurgião-dentista: a integralidade na atenção ao portador da doença, Editora Unemat, 1st edition, 2008.

[12] A. C. F. Motta, R. B. Furini, J. C. L. Simão, M. A. N. Ferreira, M. C. Komesu, and N. T. Foss, "The recurrence of leprosy reactional episodes could be associated with oral chronic infections and expression of serum IL-1, TNF- $\alpha$, IL-6, IFN- $\gamma$ and IL-10," Brazilian Dental Journal, vol. 21, no. 2, pp. 158-164, 2010.

[13] A. C. F. Motta, R. B. Furini, J. C. L. Simão et al., "Could leprosy reaction episodes be exacerbated by oral infections?" Revista da Sociedade Brasileira de Medicina Tropical, vol. 44, no. 5, pp. 633635, 2011.

[14] A. C. F. Motta, J. C. L. Simão, R. B. Furini et al., "Oral coinfection can stress peripheral lymphocyte to inflammatory activity in leprosy," Revista da Sociedade Brasileira de Medicina Tropical, vol. 46, no. 1, pp. 73-78, 2013.

[15] Ministério da Saúde and Departamento de Atenção Básica, Coordenação Geral de Saúde Bucal, Resultados Principais, Pesquisa Nacional de Saúde Bucal, Brasília, Brazil, 2010.
[16] J. M. Núñez-Martí, J. V. Bagán, C. Scully, and M. Peñarrocha, "Leprosy: dental and periodontal status of the anterior maxilla in 76 patients," Oral Diseases, vol. 10, no. 1, pp. 19-21, 2004.

[17] A. S. Tonello, Saúde bucal em portadores de hanseníase [M.S. thesis], Universidade do Sagrado Coração, Bauru, Brazil, 2005.

[18] P. C. Belmonte, M. C. Virmond, A. S. Tonello, G. C. Belmonte, and J. F. Monti, "Characteristics of periodontal disease in leprosy," BEPA-Boletim Epidemiológico Paulista, vol. 4, no. 44, pp. 4-9, 2007.

[19] V. A. Souza, A. Emmerich, E. M. Coutinho et al., "Dental and oral condition in leprosy patients from Serra, Brazil," Leprosy Review, vol. 80, no. 2, pp. 156-163, 2009.

[20] S. M. Rawlani, S. Rawlani, S. Degwekar, R. R. Bhowte, and M. Motwani, "Oral Health Status and alveolar bone loss in treated leprosy patients of Central India," Indian Journal of Leprosy, vol. 83, no. 4, pp. 215-224, 2011.

[21] J. R. Almeida, C. H. Alencar, J. C. Barbosa, A. A. Dias, and M. E. Almeida, "Surgeon-dentist contribution in the control of leprosy," Cadernos Saúde Coletiva, vol. 19, pp. 271-277, 2011.

[22] R. V. Oppermann and C. K. Rösing, "Prevenção e tratamento das doenças periodontais," in Promoção de Saúde Bucal, L. Kriger, Ed., pp. 265-286, Artes Médicas, São Paulo, Brazil, 3rd edition, 2003.

[23] M. Muthukuru, R. Jotwani, and C. W. Cutler, "Oral mucosal endotoxin tolerance induction in chronic periodontitis," Infection and Immunity, vol. 73, no. 2, pp. 687-694, 2005.

[24] D. Bassani and N. A. Lunardelli, "Condições periodontais," in Fundamentos de Odontologia. Epidemiologia da Saúde Bucal, C. J. O. Coordenador, Ed., pp. 68-82, Guanabara Kogan, Rio de Janeiro, Brazil, 1st edition, 2006.

[25] M. Yamamura, X.-H. Wang, J. D. Ohmen et al., "Cytokine patterns of immunologically mediated tissue damage," The Journal of Immunology, vol. 149, no. 4, pp. 1470-1475, 1992.

[26] V. A. Belgaumkar, N. R. Gokhale, P. M. Mahajan, R. Bharadwaj, D. P. Pandit, and S. Deshpande, "Circulating cytokine profiles in leprosy patients," Leprosy Review, vol. 78, no. 3, pp. 223-230, 2007.

[27] V. A. Mendonça, R. D. Costa, G. E. B. A. de Melo, C. M. Antunes, and A. L. Teixeira, "Immunology of leprosy," Anais Brasileiros de Dermatologia, vol. 83, no. 4, pp. 343-350, 2008.

[28] E. J. Ohlrich, M. P. Cullinan, and G. J. Seymour, "The immunopathogenesis of periodontal disease," Australian Dental Journal, vol. 54, supplement 1, pp. S2-S10, 2009.

[29] D. N. J. Lockwood, L. Suneetha, K. De Sagili et al., "Cytokine and protein markers of leprosy reactions in skin and nerves: baseline results for the north indian INFIR cohort," PLoS Neglected Tropical Diseases, vol. 5, no. 12, Article ID e1327, 2011.

[30] M. P. Cullinan, P. J. Ford, and G. J. Seymour, "Periodontal disease and systemic health: current status," Australian Dental Journal, vol. 54, pp. S62-S69, 2009.

[31] F. M. Aarestrup, M. A. Aquino, J. M. Castro, and D. N. Nascimento, "The periodontal disease in leprosy," Periodontia, vol. 4, pp. 191-193, 1995.

[32] "Parameter on periodontitis associated with systemic conditions. American Academy of Periodontology," Journal of Periodontology, vol. 71, no. 5, supplement, pp. 876-879, 2000.

[33] American Academy of Periodontology, "Parameter on systemic conditions affected by periodontal diseases," Journal of Periodontology, vol. 71, pp. 880-883, 2000.

[34] A. N. Lunardelli, D. Bassani, J. C. Cruz, and P. Nadanovsky, "Doenças Periodontais e Doenças Sistêmicas," in Fundamentos 
de Odontologia. Epidemiologia da Saúde Bucal, J. L. Antunes and M. A. Peres, Eds., pp. 279-294, Guanabara Kogan, Rio de Janeiro, Brazil, 1st edition, 2006.

[35] P. E. Sánchez-Hernández, A. L. Zamora-Perez, M. FuentesLerma, C. Robles-Gómez, R. P. Mariaud-Schmidt, and C. Guerrero-Velázquez, "IL-12 and IL-18 levels in serum and gingival tissue in aggressive and chronic periodontitis," Oral Diseases, vol. 17, no. 5, pp. 522-529, 2011.

[36] P. M. Preshaw and J. J. Taylor, "How has research into cytokine interactions and their role in driving immune responses impacted our understanding of periodontitis?" Journal of Clinical Periodontology, vol. 38, no. 11, pp. 60-84, 2011.

[37] D. Pandhi and N. Chhabra, "New insights in the pathogenesis of type 1 and type 2 lepra reaction," Indian Journal of Dermatology, Venereology and Leprology, vol. 79, no. 6, pp. 739-749, 2013.

[38] T. Yucel-Lindberg and T. Båge, "Inflammatory mediators in the pathogenesis of periodontitis," Expert Reviews in Molecular Medicine, vol. 15, article e7, 2013.

[39] R. M. Teles, M. O. Moraes, N. T. Geraldo, A. M. Salles, E. N. Sarno, and E. P. Sampaio, "Differential TNF $\alpha$ mRNA regulation detected in the epidermis of leprosy patients," Archives of Dermatological Research, vol. 294, no. 8, pp. 355-362, 2002.

[40] M. M. Stefani, J. G. Guerra, A. L. M. Sousa et al., "Potential plasma markers of type 1 and type 2 leprosy reactions: a preliminary report," BMC Infectious Diseases, vol. 9, article 75, 2009.

[41] A. L. M. Sousa, V. M. Fava, L. H. Sampaio et al., "Genetic and immunological evidence implicates interleukin 6 as a susceptibility gene for leprosy type 2 reaction," The Journal of Infectious Diseases, vol. 205, no. 9, pp. 1417-1424, 2012.

[42] W. A. Bretz, R. J. Weyant, P. M. Corby et al., "Systemic inflammatory markers, periodontal diseases, and periodontal infections in an elderly population," Journal of the American Geriatrics Society, vol. 53, no. 9, pp. 1532-1537, 2005.

[43] R. B. Johnson and F. G. Serio, "The contribution of interleukin13 and -15 to the cytokine network within normal and diseased gingiva," Journal of Periodontology, vol. 78, no. 4, pp. 691-695, 2007.

[44] A. B. Kokkas, A. Goulas, K. Varsamidis, V. Mirtsou, and D. Tziafas, "Irreversible but not reversible pulpitis is associated with up-regulation of tumour necrosis factor-alpha gene expression in human pulp," International Endodontic Journal, vol. 40, no. 3 , pp. 198-203, 2007.

[45] R. B. Johnson and F. G. Serio, "Interleukin-18 concentrations and the pathogenesis of periodontal disease," Journal of Periodontology, vol. 76, no. 5, pp. 785-790, 2005.

[46] M. C. Rodríguez and C. P. López, "Quantification of interleukin6 in periodontal tissues," Revista-Fundación Juan José Carraro, vol. 10, pp. 9-18, 2005.

[47] R. B. Johnson, N. Wood, and F. G. Serio, "Interleukin-11 and IL-17 and the pathogenesis of periodontal disease," Journal of Periodontology, vol. 75, no. 1, pp. 37-43, 2004.

[48] J. M. McGee, M. A. Tucci, T. P. Edmundson, C. L. Serio, and R. B. Johnson, "The relationship between concentrations of proinflammatory cytokines within gingiva and the adjacent sulcular depth," Journal of Periodontology, vol. 69, no. 8, pp. 865871, 1998.

[49] Y. Yue, Q. Liu, C. Xu et al., "Comparative evaluation of cytokines in gingival crevicular fluid and saliva of patients with aggressive periodontitis," International Journal of Biological Markers, vol. 28, no. 1, pp. 108-112, 2013.
[50] L. M. Shaddox, J. Wiedey, N. L. Calderon et al., "Local inflammatory markers and systemic endotoxin in aggressive periodontitis," Journal of Dental Research, vol. 90, no. 9, pp. 1140-1144, 2011.

[51] M. Robati, A. Ranjbari, M. G. Boroujerdnia, and Z. Chinipardaz, "Detection of IL-4, IL-6 and IL-12 serum levels in generalized aggressive periodontitis," Iranian Journal of Immunology, vol. 8, no. 3, pp. 170-175, 2011.

[52] T. Murata, H. Miyazaki, H. Senpuku, and N. Hanada, "Periodontitis and serum interleukin-6 levels in the elderly," Japanese Journal of Infectious Diseases, vol. 54, no. 2, pp. 69-71, 2001.

[53] P. C. Trevilatto, A. P. de Souza Pardo, R. M. Scarel-Caminaga et al., "Association of IL1 gene polymorphisms with chronic periodontitis in Brazilians," Archives of Oral Biology, vol. 56, no. 1, pp. 54-62, 2011.

[54] M.-Y. Shao, P. Huang, R. Cheng, and T. Hu, "Interleukin-6 polymorphisms modify the risk of periodontitis: a systematic review and meta-analysis," Journal of Zhejiang University: Science B, vol. 10, no. 12, pp. 920-927, 2009.

[55] A. C. F. Motta, K. J. Pereira, D. C. Tarquínio, M. B. Vieira, K. Miyake, and N. T. Foss, "Leprosy reactions: coinfections as a possible risk factor," Clinics, vol. 67, no. 10, pp. 1145-1148, 2012.

[56] R. Górska, H. Gregorek, J. Kowalski, A. Laskus-Perendyk, M. Syczewska, and K. Madaliński, "Relationship between clinical parameters and cytokine profiles in inflamed gingival tissue and serum samples from patients with chronic periodontitis," Journal of Clinical Periodontology, vol. 30, no. 12, pp. 1046-1052, 2003.

[57] B. R. Santos, Immunohistochemical analysis of proteins related to the Th1, Th2 and Th17 cells in periodontal disease [Thesis], Federal University of Rio Grande do Norte, Natal, Brazil, 2011.

[58] N. Dutzan, R. Vernal, M. Hernandez et al., "Levels of interferongamma and transcription factor T-bet in progressive periodontal lesions in patients with chronic periodontitis," Journal of Periodontology, vol. 80, no. 2, pp. 290-296, 2009.

[59] T. Honda, H. Domon, T. Okui, K. Kajita, R. Amanuma, and K. Yamazaki, "Balance of inflammatory response in stable gingivitis and progressive periodontitis lesions," Clinical \& Experimental Immunology, vol. 144, no. 1, pp. 35-40, 2006.

[60] D. F. Lappin, C. P. Macleod, A. Kerr, T. Mitchell, and D. F. Kinane, "Anti-inflammatory cytokine IL-10 and T cell cytokine profile in periodontitis granulation tissue," Clinical and Experimental Immunology, vol. 123, no. 2, pp. 294-300, 2001.

[61] N. T. Foss, "Immunological aspects of leprosy," Medicina, vol. 30, pp. 335-339, 1997.

[62] J. Venturini, C. T. Soares, A. D. F. F. Belone et al., "In vitro and skin lesion cytokine profile in Brazilian patients with borderline tuberculoid and borderline lepromatous leprosy," Leprosy Review, vol. 82, no. 1, pp. 25-35, 2011.

[63] C. E. Verhagen, E. A. Wierenga, A. A. M. Buffing, M. A. Chand, W. R. Faber, and P. K. Das, "Reversal reaction in borderline leprosy is associated with a polarized shift to type 1-like Mycobacterium leprae T cell reactivity in lesional skin: a follow-up study," Journal of Immunology, vol. 159, no. 9, pp. 4474-4483, 1997.

[64] A. E.-D. A. Moubasher, N. A. Kamel, H. Zedan, and D. E.-D. A. Raheem, "Cytokines in leprosy, I. Serum cytokine profile in leprosy," International Journal of Dermatology, vol. 37, no. 10, pp. 733-740, 1998.

[65] M. O. Moraes, E. N. Sarno, A. S. Almeida et al., "Cytokine mRNA expression in leprosy: a possible role for interferon- $\gamma$ 
and interleukin-12 in reactions (RR and ENL)," Scandinavian Journal of Immunology, vol. 50, no. 5, pp. 541-549, 1999.

[66] S. L. Walker and D. N. J. Lockwood, "The clinical and immunological features of leprosy," British Medical Bulletin, vol. 77-78, no. 1, pp. 103-121, 2006.

[67] M. Abdallah, H. Emam, E. Attia, J. Hussein, and N. Mohamed, "Estimation of serum level of interleukin-17 and interleukin-4 in leprosy, towards more understanding of leprosy immunopathogenesis," Indian Journal of Dermatology, Venereology and Leprology, vol. 79, no. 6, pp. 772-776, 2013.

[68] T. Berglundh, B. Liljenberg, and J. Lindhe, "Some cytokine profiles of T-helper cells in lesions of advanced periodontitis," Journal of Clinical Periodontology, vol. 29, no. 8, pp. 705-709, 2002.

[69] C.-C. Tsai, C.-H. Ku, Y.-P. Ho, K.-Y. Ho, Y.-M. Wu, and C.C. Hung, "Changes in gingival crevicular fluid interleukin-4 and interferon-gamma in patients with chronic periodontitis before and after periodontal initial therapy," Kaohsiung Journal of Medical Sciences, vol. 23, no. 1, pp. 1-7, 2007.

[70] P. M. Duarte, M. da Rocha, E. Sampaio et al., "Serum levels of cytokines in subjects with generalized chronic and aggressive periodontitis before and after non-surgical periodontal therapy: a pilot study," Journal of Periodontology, vol. 81, no. 7, pp. 10561063, 2010.

[71] A. R. Pradeep, P. Hadge, S. Chowdhry, S. Patel, and D. Happy, "Exploring the role of Th1 cytokines: interleukin-17 and interleukin-18 in periodontal health and disease," Journal of Oral Science, vol. 51, no. 2, pp. 261-266, 2009.

[72] H. Toker, O. Poyraz, and K. Eren, "Effect of periodontal treatment on IL-1beta, IL-1ra, and IL-10 levels in gingival crevicular fluid in patients with aggressive periodontitis," Journal of Clinical Periodontology, vol. 35, no. 6, pp. 507-513, 2008.

[73] H. A. Schenkein, T. E. Koertge, C. N. Brooks, R. Sabatini, D. E. Purkall, and J. G. Tew, "IL-17 in sera from patients with aggressive periodontitis," Journal of Dental Research, vol. 89, no. 9, pp. 943-947, 2010.

[74] H. Ohyama, N. Kato-Kogoe, A. Kuhara et al., "The involvement of IL-23 and the Th17 pathway in periodontitis," Journal of Dental Research, vol. 88, no. 7, pp. 633-638, 2009.

[75] T. Honda, Y. Aoki, N. Takahashi et al., "Elevated expression of IL-17 and IL-12 genes in chronic inflammatory periodontal disease," Clinica Chimica Acta, vol. 395, no. 1-2, pp. 137-141, 2008.

[76] M. A. Martínez, G. Gratz, A. Burgos et al., "Determinación de células T CD3+, CD4+, CD8+, receptor de la célula T familias $\mathrm{V} \beta$ en biopsias de tejido gingival en pacientes con periodontitis crónica," Revista Odontológica Mexicana, vol. 10, pp. 16-23, 2006.

[77] S. Chaitanya, M. Lavania, R. P. Turankar, S. R. Karri, and U. Sengupta, "Increased serum circulatory levels of interleukin 17F in type 1 reactions of leprosy," Journal of Clinical Immunology, vol. 32, no. 6, pp. 1415-1420, 2012.

[78] F. Martiniuk, J. Giovinazzo, A. U. Tan et al., "Lessons of leprosy: the emergence of TH17 cytokines during type II reactions (ENL) is teaching us about T-cell plasticity," Journal of Drugs in Dermatology, vol. 11, pp. 626-630, 2012.

[79] V. S. Chaitanya, M. Lavania, A. Nigam et al., "Cortisol and proinflammatory cytokine profiles in type 1 (reversal) reactions of leprosy," Immunology Letters, vol. 156, no. 1-2, pp. 159-167, 2013.

[80] N. Dutzan, R. Vernal, J. P. Vaque et al., "Interleukin-21 expression and its association with proinflammatory cytokines in untreated chronic periodontitis patients," Journal of Periodontology, vol. 83, no. 7, pp. 948-954, 2012.

[81] H. Shimauchi, S.-I. Takayama, T. Imai-Tanaka, and H. Okada, "Balance of interleukin- $1 \beta$ and interleukin-1 receptor antagonist in human periapical lesions," Journal of Endodontics, vol. 24, no. 2, pp. 116-119, 1998.

[82] N. Rathnayake, S. Åkerman, B. Klinge et al., "Salivary biomarkers of oral health-a cross-sectional study," Journal of Clinical Periodontology, vol. 40, no. 2, pp. 140-147, 2013.

[83] R. Kaushik, R. K. Yeltiwar, and K. Pushpanshu, "Salivary interleukin- $1 \beta$ levels in patients with chronic periodontitis before and after periodontal phase I therapy and healthy controls: a case-control study," Journal of Periodontology, vol. 82, no. 9, pp. 1353-1359, 2011.

[84] Ö. Ö. Yücel, E. Berker, S. Gariboğlu, and H. Otlu, "Interleukin11 , interleukin- $\beta$, interleukin-12 and the pathogenesis of inflammatory periodontal diseases," Journal of Clinical Periodontology, vol. 35, no. 5, pp. 365-370, 2008.

[85] R. Menezes, T. P. Garlet, A. P. F. Trombone et al., “The potential role of suppressors of cytokine signaling in the attenuation of inflammatory reaction and alveolar bone loss associated with apical periodontitis," Journal of Endodontics, vol. 34, no. 12, pp. 1480-1484, 2008.

[86] V. Jurisic, S. Colic, and M. Jurisic, "The inflammatory radicular cysts have higher concentration of tnf-alpha in comparison to odontogenic keratocysts (odontogenic tumour)," Acta Medica (Hradec Králové), vol. 50, no. 4, pp. 233-238, 2007.

[87] I. Brekalo Pršo, W. Kocjan, H. Šimić et al., "Tumor necrosis factor-alpha and interleukin 6 in human periapical lesions," Mediators of Inflammation, vol. 2007, Article ID 38210, 4 pages, 2007.

[88] M. Garrido Flores, T. Ordenes Vitali, C. Segu Cabrera, M. Baeza Paredes, J. García-Sesnich, and M. Hernandez Ríos, "Levels of TNF- $\alpha$ increase in gingival crevicular fluid of teeth with asymptomatic apical periodontitis," Revista Clínica de Periodoncia, Implantología y Rehabilitación Oral, vol. 4, pp. 130 133, 2011.

[89] Y. Tokoro, Y. Matsuki, T. Yamamoto, T. Suzuki, and K. Hara, "Relevance of local Th2-type cytokine mRNA expression in immunocompetent infiltrates in inflamed gingival tissue to periodontal diseases," Clinical and Experimental Immunology, vol. 107, no. 1, pp. 166-174, 1997.

[90] A. S. Ertugrul, H. Sahin, A. Dikilitas, N. Alpaslan, and A. Bozoglan, "Comparison of CCL28, interleukin-8, interleukin$1 \beta$ and tumor necrosis factor-alpha in subjects with gingivitis, chronic periodontitis and generalized aggressive periodontitis," Journal of Periodontal Research, vol. 48, no. 1, pp. 44-51, 2013.

[91] M. F. Bastos, J. A. Lima, P. M. Vieira, M. J. Mestnik, M. Faveri, and P. M. Duarte, "TNF- $\alpha$ and IL- 4 levels in generalized aggressive periodontitis subjects," Oral Diseases, vol. 15, no. 1, pp. 82-87, 2009.

[92] B. D. Frodge, J. L. Ebersole, R. J. Kryscio, M. V. Thomas, and C. S. Miller, "Bone remodeling biomarkers of periodontal disease in saliva," Journal of Periodontology, vol. 79, no. 10, pp. 1913-1919, 2008.

[93] A. Mathur, B. Michalowicz, M. Castillo, and D. Aeppli, "Interleukin-1 alpha, interleukin-8 and interferon-alpha levels in gingival crevicular fluid," Journal of Periodontal Research, vol. 31, no. 7, pp. 489-495, 1996.

[94] Y. Ishihara, T. Nishihara, T. Kuroyanagi et al., "Gingival crevicular interleukin-1 and interleukin-1 receptor antagonist levels in 
periodontally healthy and diseased sites," Journal of Periodontal Research, vol. 32, no. 6, pp. 524-529, 1997.

[95] A. U. Chaudhari, G. N. Byakod, P. F. Waghmare, and V. M. Karhadkar, "Correlation of levels of interleukin- $1 \beta$ in gingival crevicular fluid to the clinical parameters of chronic periodontitis," Journal of Contemporary Dental Practice, vol. 12, no. 1, pp. 52-59, 2011.

[96] C. Perozini, P. C. A. Chibebe, M. V. P. Leao, C. D. S. Queiroz, and D. Pallos, "Gingival crevicular fluid biochemical markers in periodontal disease: a cross-sectional study," Quintessence International, vol. 41, no. 10, pp. 877-883, 2010.

[97] R. P. Teles, D. Sakellari, F. Teles et al., "Relationships among gingival crevicular fluid biomarkers, clinical parameters of periodontal disease, and the subgingival microbiota," Journal of Periodontology, vol. 81, no. 1, pp. 89-98, 2010.

[98] R. P. Teles, L. C. Gursky, M. Faveri et al., "Relationships between subgingival microbiota and GCF biomarkers in generalized aggressive periodontitis," Journal of Clinical Periodontology, vol. 37, no. 4, pp. 313-323, 2010.

[99] G. V. Nicolau, A. Rapoport, and M. A. Selski, "Concentration of interleukin $1 \beta$ in periodontal disease," Brazilian Journal of Otorhinolaryngology, vol. 69, pp. 186-191, 2003.

[100] P. Sreenivasan, R. S. Misra, D. Wilfred, and I. Nath, "Lepromatous leprosy patients show $\mathrm{T}$ helper 1-like cytokine profile with differential expression of interleukin-10 during type 1 and 2 reactions," Immunology, vol. 95, no. 4, pp. 529-536, 1998.

[101] R. L. Modlin, “The innate immune response in leprosy," Current Opinion in Immunology, vol. 22, no. 1, pp. 48-54, 2010.

[102] N. Buduneli and D. F. Kinane, "Host-derived diagnostic markers related to soft tissue destruction and bone degradation in periodontitis," Journal of Clinical Periodontology, vol. 38, no. 11, pp. 85-105, 2011.

[103] L. Z. Dias, S. A. Piol, and C. S. de Almeida, "Atual classificação das doenças periodontais," UFES Revista de Odontologia, vol. 8, pp. 59-65, 2006.

[104] V. Mittal, R. P. Bhullar, R. Bansal, K. Singh, A. Bhalodi, and P. K. Khinda, "A practicable approach for periodontal classification," Dental Research Journal, vol. 10, pp. 697-703, 2013.

[105] J. S. Kinney, T. Morelli, T. Braun et al., "Saliva/pathogen biomarker signatures and periodontal disease progression," Journal of Dental Research, vol. 90, no. 6, pp. 752-758, 2011.

[106] Ö. Özçaka, A. Nalbantsoy, and N. Buduneli, "Interleukin-17 and interleukin-18 levels in saliva and plasma of patients with chronic periodontitis," Journal of Periodontal Research, vol. 46, no. 5, pp. 592-598, 2011.

[107] H. R. Abdolsamadi, M. Vahedi, F. Esmaeili, S. Nazari, and S. Abdollahzadeh, "Serum interleukin-6 as a serologic marker of chronic periapical lesions: a case-control study," Journal of Dental Research, Dental Clinics, Dental Prospects, vol. 2, pp. 4347, 2008.

[108] A. C. de Queiroz, M. Taba, A. P. O’Connell et al., "Inflammation markers in healthy and periodontitis patients. A preliminary data screening," Brazilian Dental Journal, vol. 19, no. 1, pp. 38, 2008.

[109] N. Dutzan, C. Rivas, J. García-Sesnich et al., "Levels of interleukin-21 in patients with untreated chronic periodontitis," Journal of Periodontology, vol. 82, no. 10, pp. 1483-1489, 2011.

[110] S. Y. Fukada, T. A. Silva, G. P. Garlet, A. L. Rosa, J. S. Da Silva, and F. Q. Cunha, "Factors involved in the T helper type 1 and type 2 cell commitment and osteoclast regulation in inflammatory apical diseases," Oral Microbiology and Immunology, vol. 24, no. 1, pp. 25-31, 2009.
[111] M. Zehnder, N. Delaleu, Y. Du, and M. Bickel, "Cytokine gene expression-part of host defence in pulpitis," Cytokine, vol. 22, no. 3-4, pp. 84-88, 2003.

[112] S. Pezelj-Ribaric, I. Anic, I. Brekalo, I. Miletic, M. Hasan, and M. Simunovic-Soskic, "Detection of tumor necrosis factor $\alpha$ in normal and inflamed human dental pulps," Archives of Medical Research, vol. 33, no. 5, pp. 482-484, 2002.

[113] J. Danin, L. E. Linder, G. Lundqvist, and L. Andersson, "Tumor necrosis factor-alpha and transforming growth factor-betal in chronic periapical lesions," Oral Surgery, Oral Medicine, Oral Pathology, Oral Radiology, and Endodontics, vol. 90, no. 4, pp. 514-517, 2000.

[114] R. A. Barkhordar, C. Hayashi, and M. Z. Hussain, "Detection of interleukin-6 in human dental pulp and periapical lesions," Endodontics and Dental Traumatology, vol. 15, no. 1, pp. 26-27, 1999.

[115] G. T.-J. Huang, A. P. Potente, J.-W. Kim, N. Chugal, and X. Zhang, "Increased interleukin-8 expression in inflamed human dental pulps," Oral Surgery, Oral Medicine, Oral Pathology, Oral Radiology, and Endodontology, vol. 88, no. 2, pp. 214-220, 1999.

[116] C. R. Rauschenberger, "Detection of human IL-2 in normal and inflamed dental pulps," Journal of Endodontics, vol. 23, no. 6, pp. 366-370, 1997.

[117] E. A. Roberts, K. A. McCaffery, and S. M. Michalek, "Profile of cytokine mRNA expression in chronic adult periodontitis," Journal of Dental Research, vol. 76, no. 12, pp. 1833-1839, 1997.

[118] F. A. Roberts, R. D. Hockett Jr., R. P. Bucy, and S. M. Michalek, "Quantitative assessment of inflammatory cytokine gene expression in chronic adult periodontitis," Oral Microbiology and Immunology, vol. 12, no. 6, pp. 336-344, 1997.

[119] Z. Y. Ay, G. Yilmaz, M. Özdem et al., “The gingival crevicular fluid levels of interleukin-11 and interleukin-17 in patients with aggressive periodontitis," Journal of Periodontology, vol. 83, no. 11, pp. 1425-1431, 2012.

[120] P. Stashenko, T. van Dyke, P. Tully, R. Kent, S. Sonis, and A. C. R. Tannerl, "Inflammation and genetic risk indicators for early periodontitis in adults," Journal of Periodontology, vol. 82, no. 4, pp. 588-596, 2011.

[121] B. Burgener, A. R. Ford, H. Situ et al., "Biologic markers for odontogenic periradicular periodontitis," Journal of Endodontics, vol. 36, no. 8, pp. 1307-1310, 2010.

[122] T. R. Fitzsimmons, A. E. Sanders, P. M. Bartold, and G. D. Slade, "Local and systemic biomarkers in gingival crevicular fluid increase odds of periodontitis," Journal of Clinical Periodontology, vol. 37, no. 1, pp. 30-36, 2010.

[123] Z. Y. Ay, R. Sütçü, E. Uskun, F. Y. Bozkurt, and E. Berker, "The impact of the IL-11:IL-17 ratio on the chronic periodontitis pathogenesis: a preliminary report," Oral Diseases, vol. 15, no. 1, pp. 93-99, 2009.

[124] T. R. Fitzsimmons, A. E. Sanders, G. D. Slade, and P. M. Bartold, "Biomarkers of periodontal inflammation in the Australian adult population," Australian Dental Journal, vol. 54, no. 2, pp. 115-122, 2009.

[125] R. P. Teles, V. Likhari, S. S. Socransky, and A. D. Haffajee, "Salivary cytokine levels in subjects with chronic periodontitis and in periodontally healthy individuals: a cross-sectional study," Journal of Periodontal Research, vol. 44, no. 3, pp. 411417, 2009.

[126] S. I. Tobón-Arroyave, P. E. Jaramillo-González, and D. M. Isaza-Guzmán, "Correlation between salivary IL- $1 \beta$ levels and periodontal clinical status," Archives of Oral Biology, vol. 53, no. 4, pp. 346-352, 2008. 
[127] A. Gürkan, G. Emingil, S. Çinarcik, and A. Berdeli, "Gingival crevicular fluid transforming growth factor- $\beta 1$ in several forms of periodontal disease," Archives of Oral Biology, vol. 51, no. 10, pp. 906-912, 2006.

[128] X. Guo, Z. Niu, M. Xiao, L. Yue, and H. Lu, "Detection of interleukin-8 in exudates from normal and inflamed human dental pulp tissues," The Chinese Journal of Dental Research, vol. 3, no. 1, pp. 63-66, 2000.

[129] N. K. Madan, K. Agarwal, and R. Chander, "Serum cytokine profile in leprosy and its correlation with clinico-histopathological profile," Leprosy Review, vol. 82, no. 4, pp. 371-382, 2011.

[130] A. Iyer, M. Hatta, R. Usman et al., "Serum levels of interferon$\gamma$, tumour necrosis factor- $\alpha$, soluble interleukin-6R and soluble cell activation markers for monitoring response to treatment of leprosy reactions," Clinical and Experimental Immunology, vol. 150, no. 2, pp. 210-216, 2007.

[131] W. R. Faber, A. M. Iyer, T. T. Fajardo et al., "Serial measurement of serum cytokines, cytokine receptors and neopterin in leprosy patients with reversal reactions," Leprosy Review, vol. 75, no. 3, pp. 274-281, 2004. 


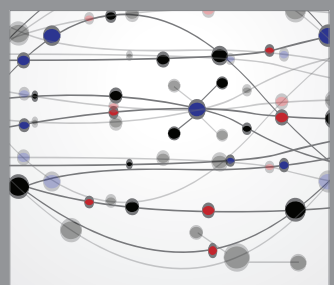

The Scientific World Journal
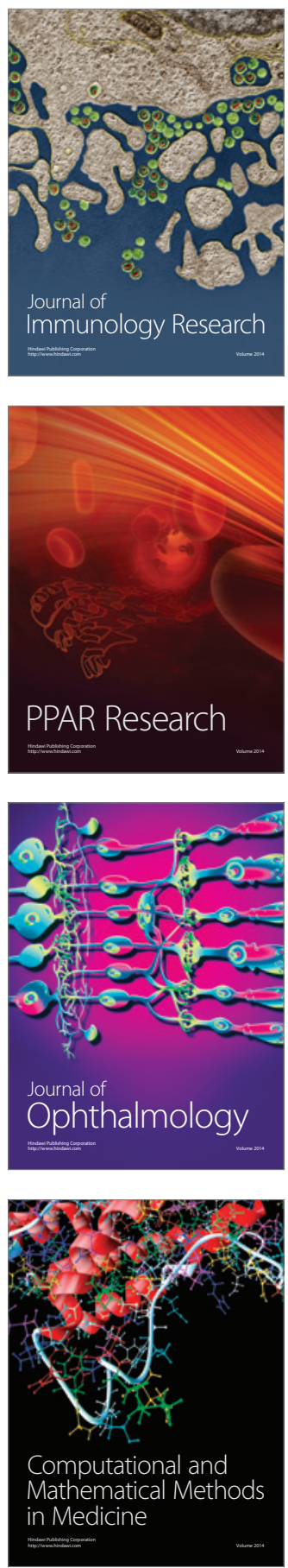

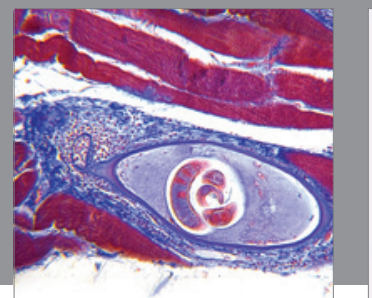

Gastroenterology

Research and Practice
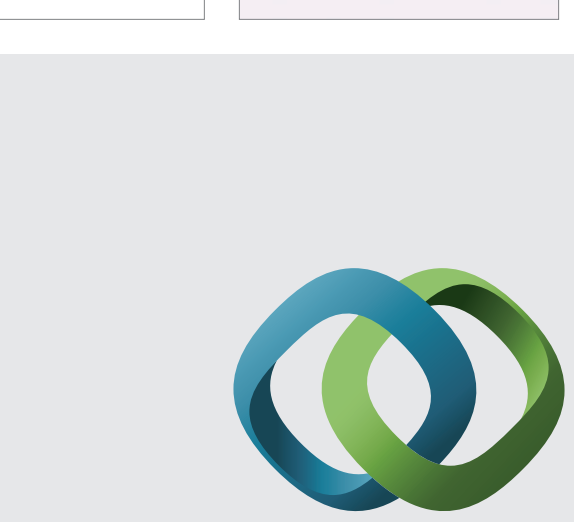

\section{Hindawi}

Submit your manuscripts at

http://www.hindawi.com
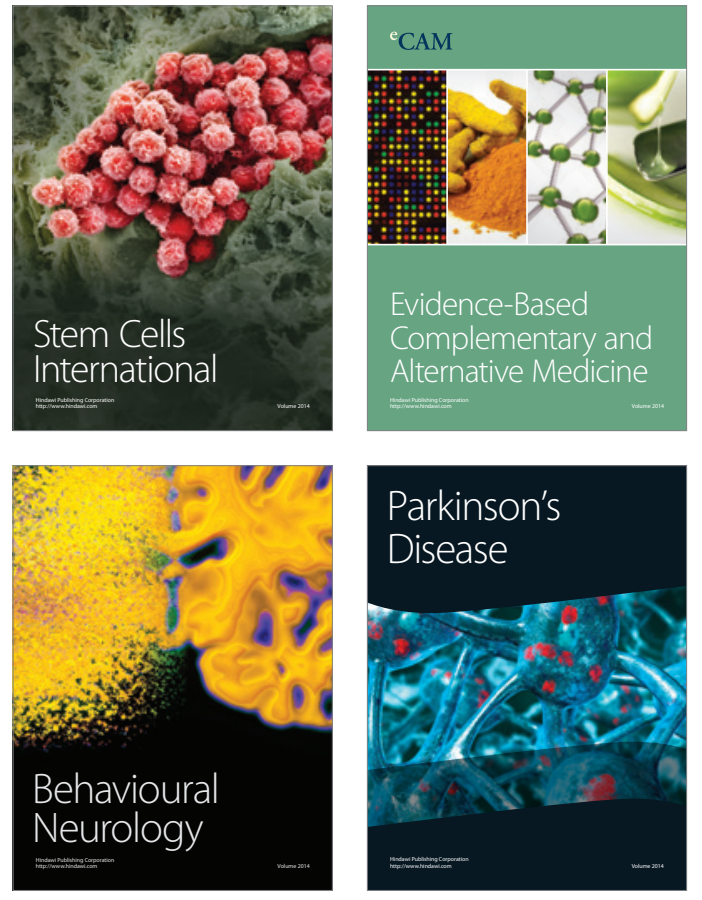
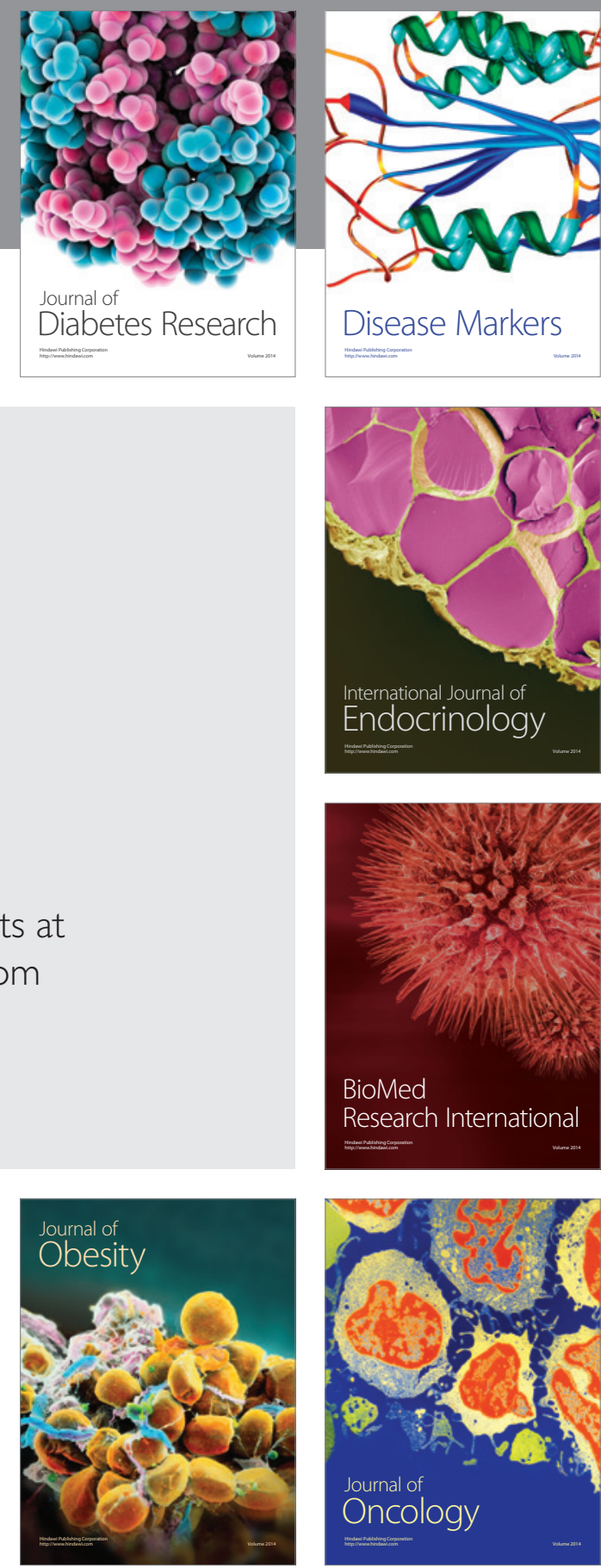

Disease Markers
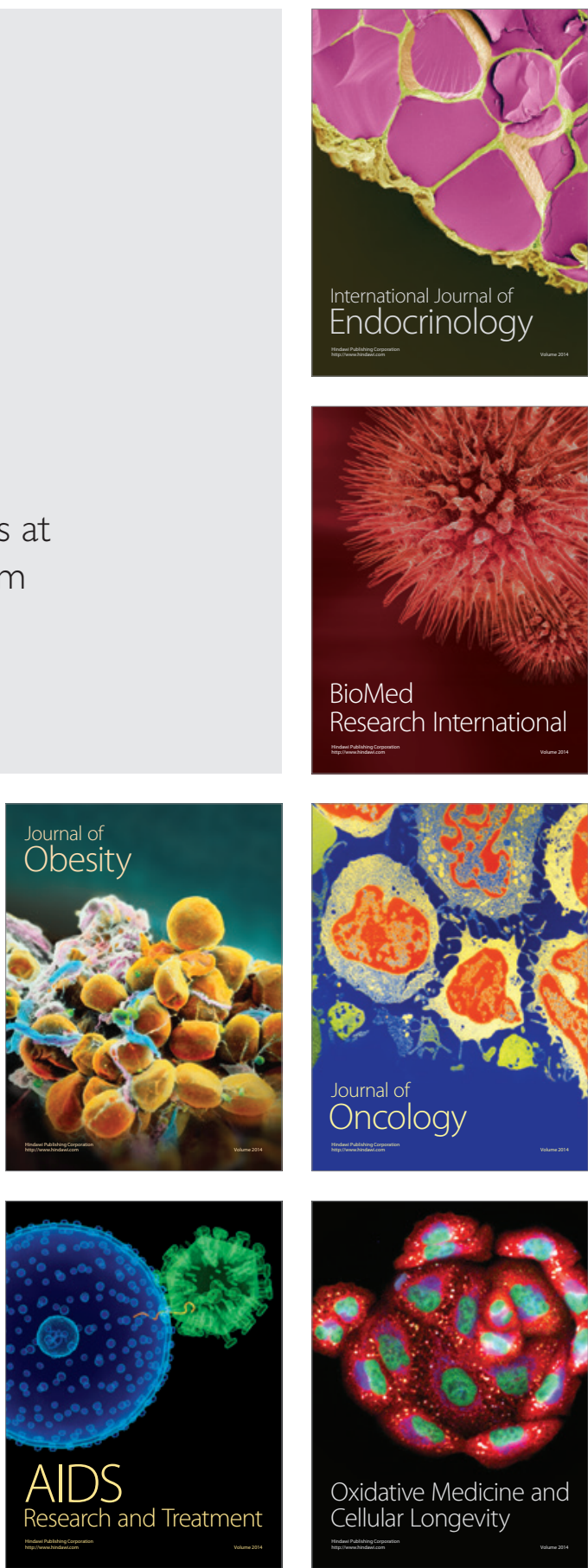